\title{
Exchange Rate Volatility and Its Implications on Macroeconomic Variables in East African Countries ${ }^{1}$
}

\author{
Nicas Yabu ${ }^{1} \&$ Deogratius Kimolo ${ }^{1}$ \\ ${ }^{1}$ Bank of Tanzania, Tanzania \\ Correspondence: Nicas Yabu, Bank of Tanzania, Tanzania.
}

Received: March 9, 2020

Accepted: April 17, 2020

Available online: May 19, 2020

doi:10.11114/aef.v7i3.4859

URL: https://doi.org/10.11114/aef.v7i3.4859

\begin{abstract}
The study examines the extent of exchange rate volatility and its impact on key macroeconomic variables such as exports, FDI inflows, interest rate and inflation in Tanzania, Kenya and Uganda. The GARCH model is used to compute the extent of exchange rate volatility while the Panel Autoregressive Distributed Lag (ARDL) technique or pooled mean group (PMG) estimator was used to estimate the effects of exchange rate volatility on selected macroeconomic variables. The results indicate that volatility in the exchange rate is a real issue in all the sampled countries and is fundamentally driven by exports and FDI dynamics for the period under consideration. The results indicate a positive impact of the exchange rate volatility to export performance and lending rates in the long run. Exchange rate volatility appears to be detrimental to both export performance and leads to a reduction in lending rates in the short run. Also, the response of FDI to exchange rate volatility seems to be negative in the long run while in the short run the response from the volatility of real exchange rate seems is insignificant. Though not significant, the volatility of the exchange rate appears to have a positive impact on inflation. The study recommends that policymakers need institute mitigation measures which could smooth out excessive exchange rate volatility to minimize its likely impact on the economy. The study also indicated a need for the EAC countries to consider adopting inflation targeting monetary policy framework in order to contain inflation at the appropriate level.
\end{abstract}

Keywords: exchange rate, volatility, inflation, trade flows, interest rate, exports, FDI

\section{Introduction}

During the early 1990s, ${ }^{2}$ all EAC countries adopted a range of reforms supported by the IMF/World Bank under the Structural Adjustment Programme. These reforms among others were geared towards more outward-looking trade and market-determined exchange rate policies. Since the adoption of market-determined exchange rate regimes, exchange rates of the EAC member states have been subjected to periodic variations. In some EAC member states, these exchange rate variations have sometimes been too high resulting into volatilities due to domestic and foreign shocks. Such volatility may translate into reduced trade flows, Foreign Direct Investment (FDI), and instability in both interest rates and inflation rates.

Instability in macroeconomic variables imposes a real cost to households' decision making, firms' profitability, financial stability and a country economic performance with regards to export performance, interest rates, foreign direct investment as well as the inflation. For instance, researchers have argued that excessive exchange volatility has reduced economic growth through its impact on trade and investment. A study by Horvath (2005) argued that excessive exchange rate volatility triggers uncertainties, which, in turn, sends bad signal to investors. These uncertainties are known to negatively impact the real economic growth by creating uncertainty about the profits, level of unemployment,

\footnotetext{
${ }^{1}$ Tanzania, Kenya and Uganda are the only three EAC countries covered under this study due to long-term historical relationship and data availability.

${ }^{2}$ It should however be noted that in the 1990's Kenya was long ahead with the IMF/World Bank and as such structural reforms in Kenya were home grown without support from the Bretton Wood Institutions. Further, Kenya has always been a market driven economy (unlike Tanzania and Uganda) - to the extent that exchange rates were market driven (could be with some interventions).
} 
as well as poverty. The study by Schnabl (2009) also found that excess exchange rate volatility exerts a negative impact on growth for a sample of emerging European and East Asian countries.

There are growing and firm evidences that exchange rate volatility which is defined as "instability, fickleness or uncertainty" and is also as a measure of risk associated with exchange rate movements imposes significant effects on the volume of trade (Farrell et al. 1983; IMF, 1984; Côté, 1994; McKenzie, 1999; UK Treasury, 2003; Clark et al. 2004; and Ozturk, 2006). Hagen and Zhou (2005) pointed out that exchange rate volatility is perceived negatively, especially in the case of developing countries, in terms of its negative effect on capital inflows and investments. It is known that excess volatility in exchange rate usually restricts the international flow of capital by reducing both direct investment in foreign operating facilities, and financial portfolio investment. International trade and investment decisions also become more difficult due to volatile exchange rate because volatility increases exchange rate risk. As a result of exchange rate volatility, exporters may prefer to switch to domestic activities where profits are relatively less uncertain rather than continuing to trade in foreign markets.

Also, McKinnon and Ohno (1997) noted that excess exchange rate volatility can lead to higher prices of internationally tradable goods by causing traders to incorporate a risk premium to shelter against unanticipated exchange rate volatilities. This will ultimately add to inflationary pressures through the tradable goods.

During the second quarter of 2015, all EAC currencies recorded a substantial depreciation against other major currencies largely due to global appreciation of the US Dollar. Another round of substantial depreciation of EAC currencies has been recorded since the end of January 2017, which raises concerns about the effect of the fast rate of depreciation of the currencies on other macroeconomic variables and the economy at large.

There is a gap in information as to whether or not the recorded exchange rate movements have resulted to volatility and that to what extent such volatility has impacted to macroeconomic variables such as growth, interest rate, inflation and trade flows. It is against this backdrop that this study examined the extent of exchange rate volatility in EAC countries and identifying its subsequent impact on macro-economic variables.

The signed protocol for the establishment of a monetary union in the EAC member states is expected to bring monetary integration, stronger trade, high investment and growth. To ensure that economies going for the monetary union are highly integrated with stable macroeconomic variables, the EAC member states must fulfil certain agreed-upon requirements - the macroeconomic convergence criteria. However, the recorded fluctuations in exchange rates in those countries pose a concern about their effects on the instability of other macroeconomic variables. In addition, the uncertainty generated from exchange rate volatility creates risks to economic agents, which may distort the allocation of resources. Therefore, understanding exchange rate volatility is an issue of great importance for businesses and policymakers alike.

Businesses use volatility models as tools in their risk management and as an input in pricing derivatives, whereas knowledge about what and how economic factors are influenced by exchange rate volatility is important for informed policymaking. In addition, the interactions and interdependence of macroeconomic variables make a concern of analysing volatility in the exchange rate and its implications to macroeconomic variables in the economy. The short-and long-term independence of exchange rates with other macroeconomic economic fundamentals can lead to misalignment in social-economic variables, which in turn affect growth and poverty. In view of this, it is imperative to study the extent of exchange volatility and its likely impact on macroeconomic variables in the EAC countries.

Thus, the overall objective of the study is to examine the dynamics of exchange rate volatility and its subsequent impact on macro-economic variables in the three founder EAC Countries. More specifically, the study intends to estimate the extent of exchange rate volatility in Tanzania, Kenya and Uganda; and assess the impact of exchange rate volatility on trade flows, FDI, inflation and interest rate in Tanzania, Kenya and Uganda.

The rest of the paper is structured as follows. Section 2 presents some stylized facts with respect to the trends of the key variables of interest in the three founder EAC Countries. In section 3 a literature review is presented while section 4 presents the methodology of the study. Chapter 5 discusses the findings of the study, while the conclusion and policy implication are provided in section 6.

\section{Stylized Facts of Macroeconomic Variables}

In this section, the trend and relationship between the exchange rate and other macroeconomic variables in the economies of Tanzania, Kenya and Uganda are described using historical patterns.

\subsection{Dynamics of Macroeconomic Variables in Tanzania}

\subsubsection{Exchange Rates}

Figure 1 shows the trend in the nominal exchange rate of the Tanzanian shilling against the US dollar as well as the real effective exchange rate of the shilling against a basket of currencies. During the period under review, the shilling 
exchange rates maintained a generally upward (depreciating) trend with two episodes of sharp depreciation that can be clearly earmarked. The first episode was during the first half of 2011/12. The volatility and rapid depreciation of the shilling during the period was been caused by, among others, increase in global demand for dollars, rapid expansion in the oil imports and delays in disbursement of foreign program assistance (Bank of Tanzania, 2014). The second period of sharp depreciation is observed in 2015 mainly attributed to the global strengthening of the US dollar against other currencies due to improved economic activities in the US. The nominal exchange rate has been the major driver of the dynamics of the real effective exchange rate despite that the real effective exchange rate has been fairly stable over the period.



Figure 1. Trend of Exchange Rates in Tanzania

Source: Bank of Tanzania, Various issues

\subsubsection{Exchange Rate and Inflation}

From figure 2, two episodes of high inflation can be traced. The first episode was during 2008/09. Prior to the first episode, inflation maintained a steadily increasing trend, which was also accompanied by a depreciation of the exchange rate in real terms. Thereafter, from January 2011 inflation maintained a steady upward trend reaching a peak of 19.8 percent in December 2011. This upward trend was preceded by a trend depreciation of the shilling that started early 2010. In this period, inflation was also a result of higher world food and oil prices and aggravated further by unfavourable weather conditions in Tanzania that lead to a shortage of food supply in the market. The situation was made worse by food shortages in neighbouring countries, especially Kenya and Uganda. In the second episode of 2015 however, significant exchange rate depreciation shock didn't translate into higher inflation.

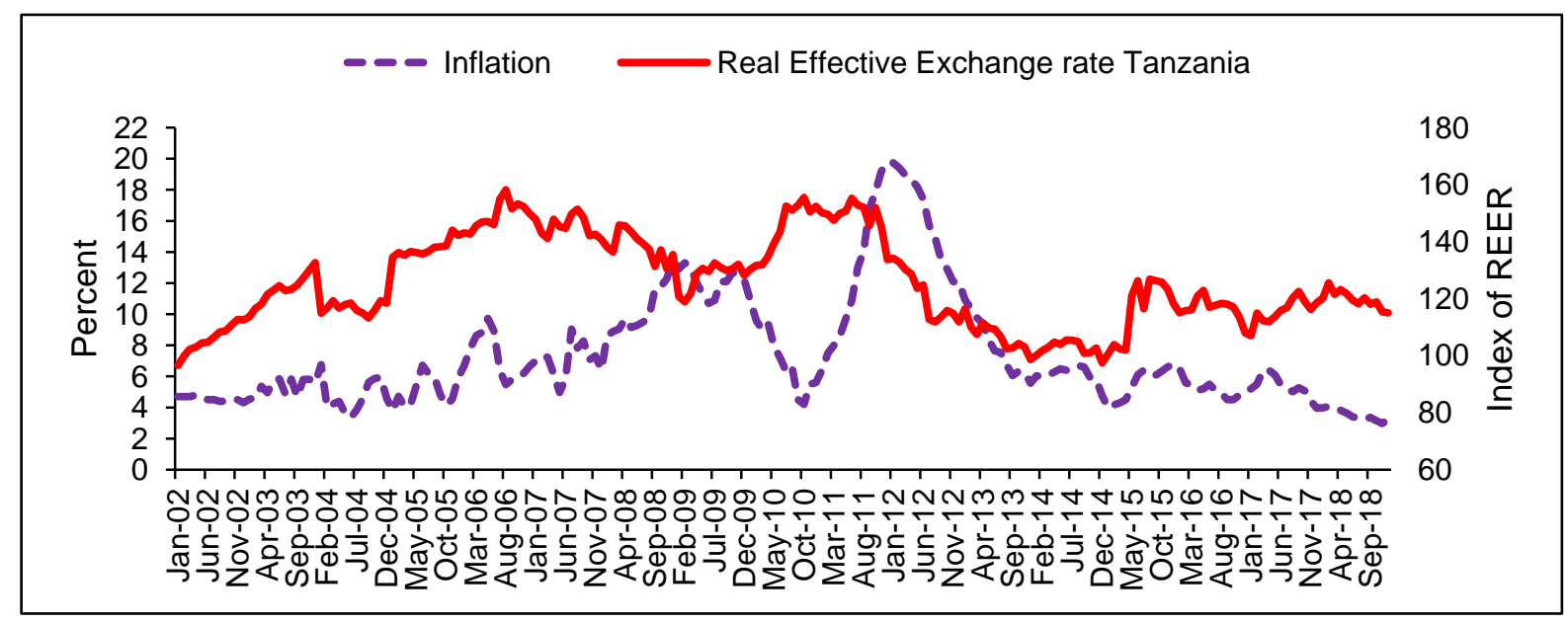

Figure 2. Trend of Real Effective Exchange Rate (REER) and Inflation in Tanzania

Source: Bank of Tanzania, Various issues 


\subsubsection{Exchange Rate and Export Performance}

Over the last 10 years, exports earnings have maintained a general steady growth in Tanzania. The exports have also become more diversified, with particularly rapid growth in exports of gold and manufacturing goods. Despite steady growth, export earnings over the period have been volatile partly (Figure 3). The question remains whether the observed variability is partly attributed by volatility in the real effective exchange rate and ultimately on the uncertainties faced by exporters.



Figure 3. Trend of Real Effective Exchange Rate (REER) and Export Performance in Tanzania

Source: Bank of Tanzania, Various issues

\subsubsection{Exchange Rate and FDI}

Since the mid-1980s in recognition of the significant role towards building an enabling environment for private sector growth, Tanzania enacted a number of investment-related laws and policies, put in place attractive investment packages, and undertook a number of other initiatives to promote and develop the private sector. Currently, Tanzania is one of the major destinations for FDI in Sub-Saharan Africa. Foreign Direct Investments (FDI) has remained high following continued investment activities in the country in projects such as natural gas, power generation, cement factory, uranium and coal mines. The strong FDI inflows are also presumed to be partly a result of a stable macroeconomic environment, including a stable exchange rate.

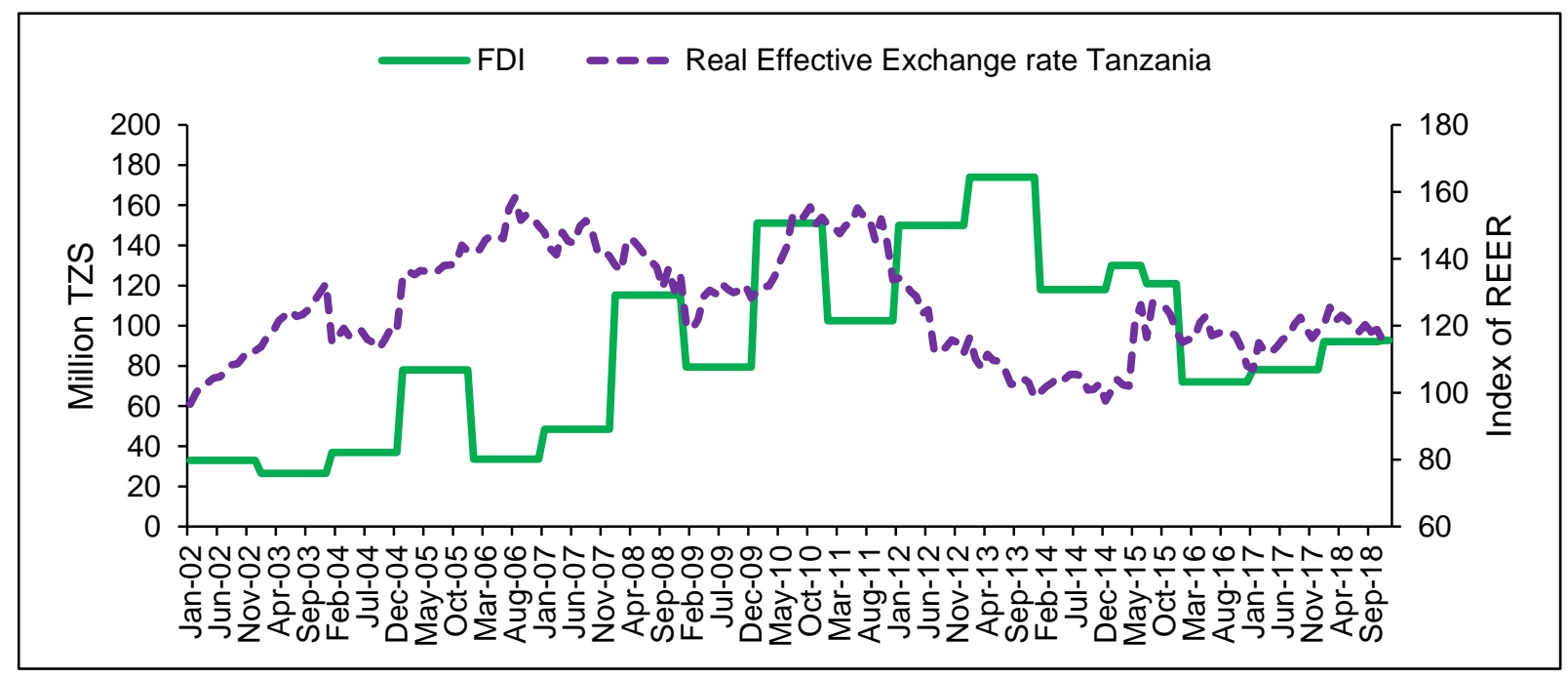

Figure 4. Trend of Real Effective Exchange Rate (REER) and FDI in Tanzania

Source: Bank of Tanzania, Various issues 


\subsubsection{Exports and FDI}

Figure 5 illustrates the movement of FDI against exports in Tanzania over the last 16 years. It is clear from the chart that the two variables co-move. Thus, the increase in the FDI in Tanzania following several reform initiatives and stable macroeconomic environment have resulted in a significant increase in exports over time. FDI has helped in transferring productivity spill over to the tradable sector and hence helped the country's exports catch up with quality frontier.



Figure 5. Trend of Real Effective Exchange Rate and FDI in Tanzania

Source: Bank of Tanzania, Various issues

\subsection{Dynamics of Macroeconomic Variables in Kenya}

\subsubsection{Exchange Rate}

The Kenyan shilling in nominal terms maintained a general stable appreciation trend before the Global Financial Crisis of 2008, while in real terms exhibited a steady depreciating trend (Figure 6). However, more excessive upward fluctuations have been observed since 2008, indicating a weakening of the shilling in nominal terms as a result of the global financial crisis (The Republic of Kenya, 2012). Thereafter, like other currencies in the world, it depreciated both in real and in nominal terms again in 2015 following global appreciation of the dollar against other currencies.



Source: Bank of Kenya

Figure 6. Trend of Nominal Exchange Rates in Kenya

\subsubsection{Exchange Rate and Inflation Dynamics}

Inflation for an open economy such as that of Kenya is driven by both domestic factors (internal pressures) as well as external factors (external pressures). External inflationary pressure mostly emanates from the rise in world prices of commodities mainly food and oil as well as fluctuation in the real exchange rate. Figure 7 indicates that the co-movement between inflation and the real effective exchange rate is more pronounced in the period before 2011; thereafter the co-movement is of little evidence afterwards partly suggesting the mild impact of exchange rate volatility on inflation. 




Figure 5. Trend of Nominal Exchange Rates (NEER) and Inflation in Kenya

Source: Bank of Kenya

\subsubsection{Exchange rate and Export Performance}

Key export commodities of Kenya have been tea and coffee, followed by horticultural products that have undergone rapid growth over the last few decades and thus Kenya's involvement in international trade continues to increase drastically. As alluded by Were et al. (2002), the structure of Kenya's export sector makes it vulnerable to fluctuations in world prices. Figure 8 indicates that exports responded well to exchange rate liberalization, and this is evident from the increase in export volumes over time, during the episodes of exchange rate depreciation, especially from 2006/07 onwards.

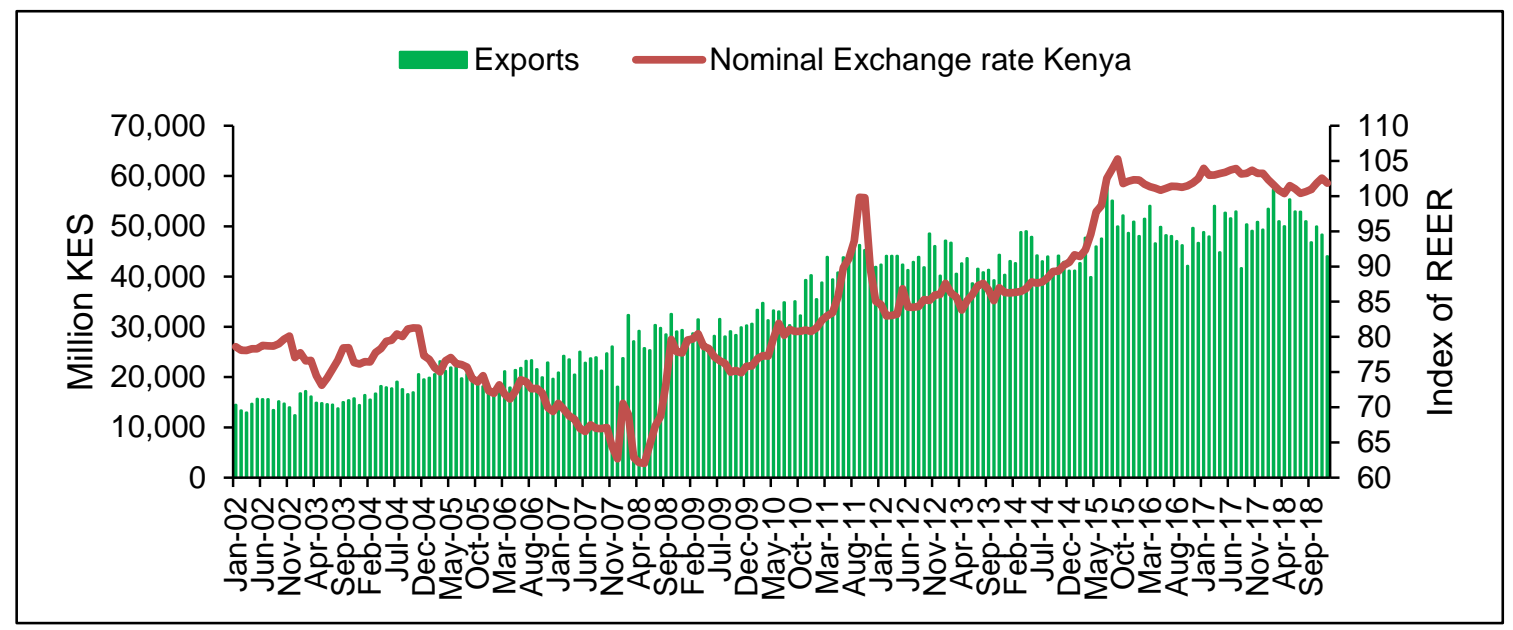

Figure 6. Trend of Nominal Exchange Rate and Export Performance in Kenya

Source: Bank of Kenya

\subsubsection{Exchange Rate and FDI}

Figure 9 indicates a weak relationship between the nominal exchange rate and FDI inflows. Before 2008, FDI inflows in Kenya remain relatively weak considering the size of its economy and its level of development. However, since 2012 the FDI flows have significantly increased making Kenya one of the largest recipients of FDI in Africa. This increase was related to investments, mainly by Chinese in the mining and hydrocarbon sectors (Central Bank of Kenya, 2016). 


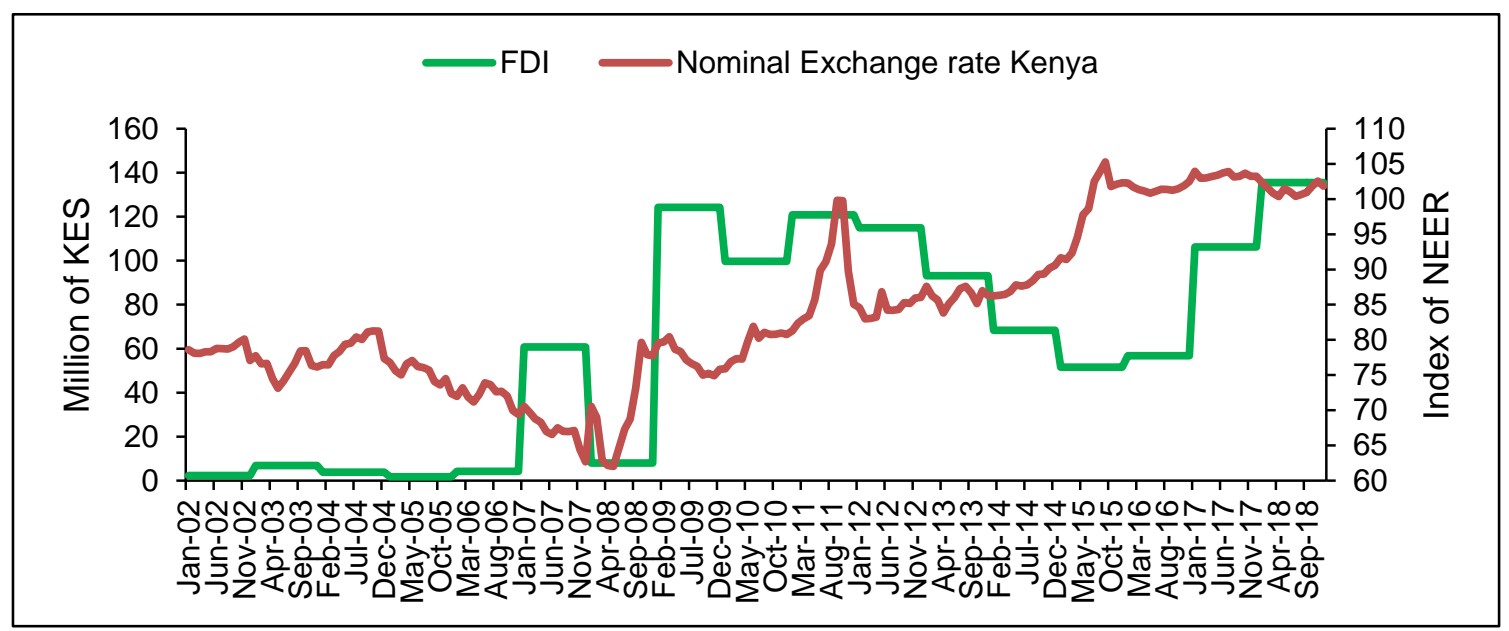

Figure 7. Nominal Exchange Rate (NEER) and FDI in Kenya

Source: Bank of Kenya

\subsubsection{Exports and FDI}

Figure 10 illustrates the movement of FDI against exports in Kenya over the last 16 years. The figure indicates a weak relationship between the FDI inflows and export performance in Kenya. While exports were on a generally increasing trend, the FDI inflows have been volatile, declining between 2012-2016.

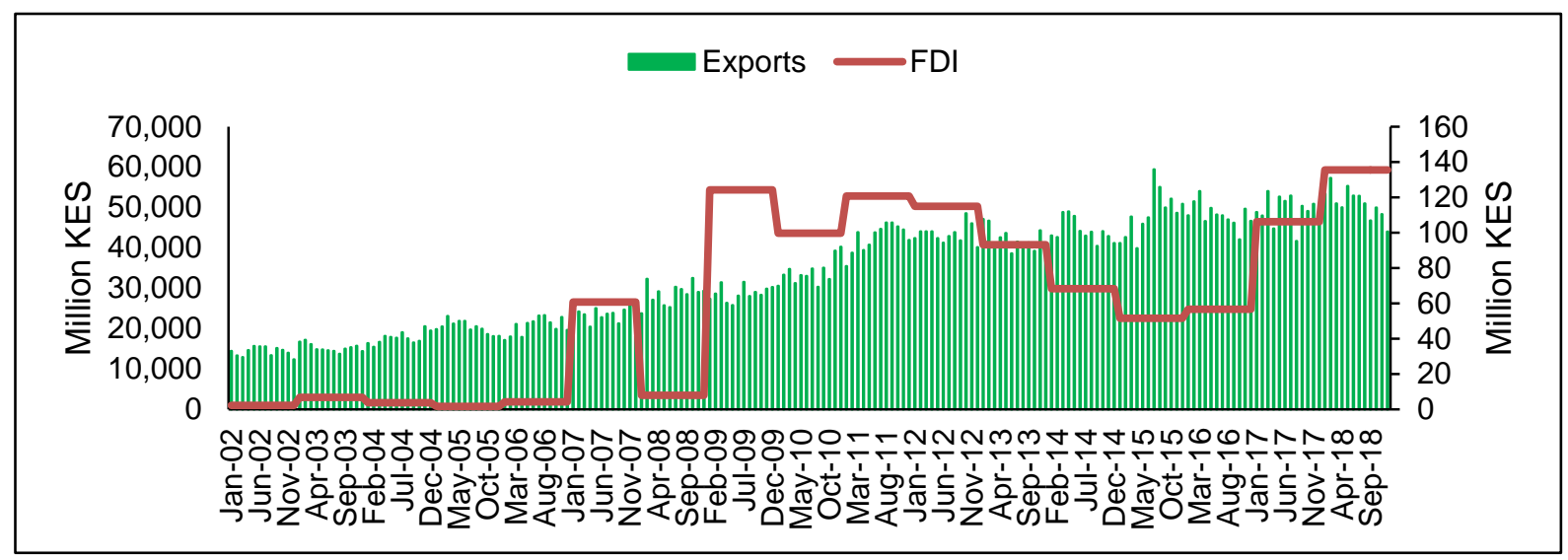

Figure 8. Trend of Exports and FDI in Kenya

Source: Bank of Kenya

\subsection{Dynamics of Macroeconomic Variables in Uganda}

\subsubsection{Exchange Rate}

Like other East African countries, the exchange rate between Ugandan shilling and other currencies especially the US Dollar has fluctuated enormously since 2002 with two episodes of sharp depreciation that can be clearly earmarked during the first half of 2011/12 and in 2015 (Figure 11). It is also worth noting that the movement of the real effective exchange in many cases is reflected by dynamics in the nominal exchange rate. 




Figure 9. Trend of Nominal Real Exchange Rates (REER) in Uganda

Source: Bank of Uganda

\subsubsection{Exchange Rate and Inflation Dynamics}

In line with a liberalised current and capital account of the balance of payments, the Bank of Uganda pursues a flexible exchange rate policy regime. The Ugandan inflation remained remarkably variable as shown in figure 12 . Like other EAC countries in 2011/12, supply-side shocks to the domestic food and international oil prices exerted significant upward pressure on domestic inflation, with headline inflation peaking at 30.5 per cent in October 2011. Co-movement between real effective exchange rate and inflation is discernible, albeit with a lag.



Figure 10. Trend of Real Effective Exchange Rate (REER) and Inflation in Uganda

Source: Bank of Uganda

\subsubsection{Exchange Rate and Export Performance in Uganda}

Uganda's exports mainly comprise agricultural products, which include coffee, cotton, tea, flowers, processed fish and fish products and vanilla among others. Trade policy reforms (trade liberalization) in the 1990's decontrolled producer prices and dismantled the monopoly power of former marketing boards both of which reinforced the exchange rate policy reform that led to considerable improvements in price incentives that resulted into positive supply responses both in terms of volume and composition of exports. Figure 13 indicates co-movement between real effective exchange rate and value of exports in Uganda particularly. 




Figure 11. Trend of Real Effective Exchange Rate (REER) and Export Performance in Uganda

Source: Bank of Uganda

\subsubsection{Exchange rate and FDI in Uganda}

Figure 14 indicates that FDI inflows in Uganda have maintained a steady increasing trend since early 2000. However, the inflows declined in 2014/15 mainly due to lower foreign investment in the oil industry (Bank of Uganda, 2016). The figure indicates a positive association between real effective exchange rate with FDI.

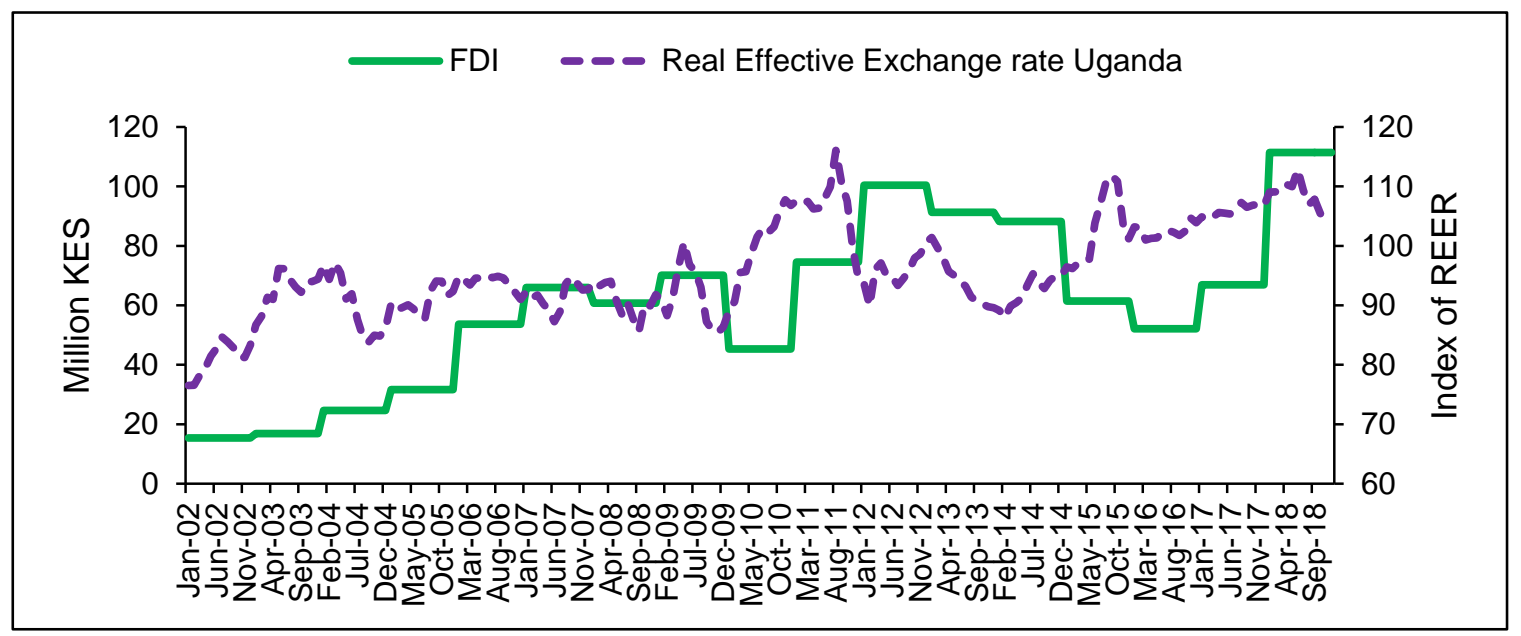

Figure 12. Trend of Real Effective Exchange Rate (REER) and FDI in Uganda

Source: Bank of Uganda

\subsubsection{Exports and FDI in Uganda}

Figure 15 illustrates the movement of FDI against exports in Uganda over the last 16 years. Like the case of Tanzania, there is a strong correlation between FDI inflows and exports in Uganda. The FDI inflows in Uganda have maintained a steady increasing trend since early 2000 consistent with an improvement in the export's performance. However, the inflows declined in 2014/15 mainly due to lower foreign investment in the oil industry (Bank of Uganda, 2016) and this was consistent with deterioration in the export performance. 




Source: Bank of Uganda

Figure 15. Trend of Exports and FDI in Uganda

\section{Literature Review}

\subsection{Theoretical Literature Review}

It is widely presumed that volatility in the exchange rates of small open market economies is one of the main sources of economic instability around the world (Gerardo and Felipe, 2002). Foreign exchange rate volatility influences the value of a firm since future cash flows of the firm will change with fluctuations in foreign exchange rates. Luehrman (1991) found that depreciation in the currency of a country affects the competitiveness of the firms engaged in international competition, leading to increased demand for its export goods. Adler and Dumas (1984) reported that although firms, whose operations are widely domestic, may be influenced by the fluctuations in foreign exchange rates, their input and output prices may be affected by currency movements.

The literature has provided extensive evidence on the link between exchange rate volatility and trade since the collapse of the Breton Woods system of the fixed exchange rate. Fluctuations in the exchange rate may negatively affect the competitiveness of tradable goods and in turn, reduce the volume of trade and worsen the balance of payments. However, whether or not a high degree of exchange-rate variability has an impact on foreign trade, continues to be an important question in most Less Developed Countries (LDCs), since it has relevance for decision making concerning choice of an exchange-rate system as well as the conduct of exchange-rate policy (Brada and Mendez, 1988; Caballero and Corbo, 1989; Arize, et. al., 2000).

The theoretical literature offers many models explaining the association between the exchange rate and the volume of trade. For instance, the model of Clark (1973) and Hooper and Kohlhagen (1978) claimed that exchange rate volatility increases the risk-averse traders and then squeezes the volume of trade. Another group of theoretical models indicate that exchange rate volatility has an unclear impact on trade, sometimes positive and other times negative (Franke 1991; Sercu and Vanhulle 1992; and De Grauwe 1988). For example, De Grauwe (1988) point out that, an increase in risk has both substitution and an income effect.

As far as the link between exchange rate volatility and FDI is concerned, theories discuss based on two wings: the production flexibility wing and the risk aversion wing. The production flexibility side, exchange rate volatility fosters FDI since foreign producers are assumed to be able to adjust the use of one of their variable factors following the realization of a stochastic input in profits (Goldberg and Kolstad 1995). For the case of the risk aversion theory, FDI decreases as exchange rate volatility increases in the sense that higher fluctuations in the exchange rate lower the certainty equivalent expected exchange rate, which in turn reduces FDI.

\subsection{Empirical Literature Review}

On the empirical side, the literature provides mixed findings, depending on the model specifications, sample periods, a proxy of trade used, other macroeconomic indicators included, and methods of measuring the exchange rate volatility and trade. For instance, Choudhury (2005) investigates the effects of the exchange rate volatility on United States exports to Canada and Japan during under the flexible exchange rate period. He used the univariate GARCH model to measure the extent of exchange rate volatility, applied the multivariate cointegration method, and constrained error correction models to study the stated relationship. He found that exchange rate volatility had a negative impact on the volume of bilateral exports. 
Also, Arize et al. (2000) investigated the exchange rate volatility on trade-proxied by exports of 13 less developed countries with quarterly data series for the period 1973-1996 using the Johansen (1991) Multivariate procedure and Error Correction Model. Their result shows a significant negative effect of volatility on export flows. The study by Broda, (2004) replicated the same by employing panel data of 75 countries for the same period of 1973-1996, using VAR model. The findings show that there were substantial shocks to terms of trade and real GDP in the short-term. The result from impulse responses indicated the presence of the negative shocks resulted from larger exchange rate changes in countries that adopted a flexible exchange rate.

According to the study by (Arize, Osangn \& Slottje, 2004), increases in the volatility of the real effective exchange rate, is usually expected to exert a significant negative impact on competitiveness of exports and ultimately reduce export demand in both the short-run and the long run and these effects may result in significant reallocation of resources by market participants. The issue is particularly important for countries that switched from a fixed to a flexible exchange rate regime due to the higher degree of volatility associated with flexible exchange rates.

Clark (1973) used panel data analysis for emerging countries and established a negative relationship between exchange rate volatility and exports. His findings were consistent with risk-averse theories in the sense that in the absence of hedging facilities while producers are risks averse, any rise in exchange rate volatility would cause them to decrease their risk exposure in order to prevent its consequence on the profitability.

On the impact of exchange rate volatility on interest rates, Study by Karfakis and Kim (1995) employed Australian exchange rate data and discovered that unanticipated current account deficit is linked with nominal exchange rate depreciation and an increase in interest rates.

Empirical evidence on the impact of exchange rate volatility on FDI flow is mixed. For example, Cushman 1988; Stokman and Vlar 1996; and Foad (2005) indicate that exchange rate volatility exerts a positive impact on FDI flow to the host countries. These findings are grounded on the fact that FDI is considered to be a substitute for exports. That is, an increase in exchange rate volatility in the host country induces a multinational firm to serve the host country via a local production facility rather than exports, thereby insulating against currency risk. The other side of empirical literature argues that exchange rate volatility negatively affects the flow of FDI (Dixit and Pindyck 1994; and Darby et al. 1999). Their argument is that a country with a high degree of exchange rate volatility would have a high degree of currency risk, which converts the flow of FDI to countries with more stable exchange rates.

Different literature records mixed results, again depending on methodology, area-specific and other macroeconomic variables used. For instance, Accam (1997) examined this relationship in some selected 20 least developed countries, using OLS estimation, and employing standard deviation as a proxy for instability in exchange rate volatility. Accam's findings indicate that there was a significant negative relationship between exchange rate uncertainty and FDI flows for the period. Alaba (2003) estimated the extent of exchange rate volatility using GARCH and its ultimate impact on FDI to agriculture and manufacturing using an error correction model in Sub-Saharan African countries. The results show that the official market exchange rate movement significantly reduces FDI inflows to agriculture and insignificant for the manufacturing FDI. Also, Chaduhary et al. (2012) used annual data from 1980 to 2010 for the sample of Asian economies by applying autoregressive distributed lag and GARCH approach to examine the effect of the volatility of exchange rate on FDI. The result shows that there is a positive and significant relationship between FDI and volatility exchange rate.

The effect of exchange rate volatility on inflation is analysed in a multi-direction view in both theory and empirical literature. For instance, Edwards (1993) findings who conducted the cross-country research in developing countries indicate that inflation is much lower and less volatile in a peg exchange rate regime than countries that practice flexible exchange rate system. The implication from Edwards' findings is that exchange rate volatility in a free-floating exchange rate regime affect inflation. Also, Odedokun (1995), using data from 35 countries for the period 1971 to 1990, obtained results suggesting that among other variables domestic currency depreciation has positive effects on inflation.

In addition, Ezirim, et al., (2012) employed the autoregressive distributed lag analytical framework to investigate the interdependencies between exchange rates and inflation rates behaviour in Nigeria. Findings indicate that exchange rates movements and inflation spiral are cointegrated, associating both in the short run and in the long run. They indicated that that in a regime of inflation targeting, exchange rate volatility might trigger high inflation; thus, a policy aimed at exchange rates manipulation becomes important. Looking at the issue from the opposite side, Bleaney and Francisco (2008) indicate that inflation targeting reduces the volatility of real exchange rate expectations, given the tendency of associating it with floating exchange rate regimes. Again, the implication from this side is that inflation is the function of exchange rates, and exchange volatility is emanated from inflation fluctuations.

Therefore, volatility in the exchange rate has a prolonged effect, which ultimately affects economic growth. For instance, Danmola (2013) analysed the impact of exchange rate volatility on macroeconomic variables in Nigeria using 
Correlation Matrix, Ordinary Least Square (OLS) and Granger Causality test. The findings show that exchange rate volatility affected FDI, trade openness, inflationary rate and Gross Domestic Product in the country.

The literature review provides a theoretical and empirical examination on exchange rate volatility and its implications on macroeconomic variables. Generally, volatility in the exchange rate has been referenced to have a significant impact on macroeconomic variables. Therefore, theoretical and empirical evidence discussed are based to establish the research methodology to be used in this study; which is presented in the following section.

\section{Methodology}

\subsection{Modelling Exchange rate Volatility}

The most common methods for generating future volatility estimates are moving average, whereby each past volatility within that time period is weighted equally in the resulting volatility estimate, and exponential smoothing model, which gives more weight to the most recent observations of volatility.

However, according to Campbell et al. (1997), it is both logically inconsistent and statistically inefficient to use volatility measures that are based on the assumption of constant volatility over some period and putting more weight on the recent observations of volatility, when the resulting series moves through time. As a results ARCH/GARCH family models, which assume that volatility changes over time, are perceived to perform better compared to the previous methods in terms of estimating volatility.

Therefore, this study uses GARCH family models to estimate the extent of exchange rate volatility. Formulation of the GARCH model follows the following steps: Let $\varepsilon_{t}$ be a random variable that has a mean and a variance conditionally on the information set $F_{\mathrm{t}-1}$ (the $\sigma$-field generated by $\varepsilon_{t-j}, \mathrm{j} \geq 1$ ). The ARCH model $\varepsilon_{t}$ has the following properties: First, $\mathrm{E}\left\{\varepsilon_{t} / F_{\mathrm{t}-1}\right\}=0$ and, second, the conditional variance $\mathrm{h}_{\mathrm{t}}=\mathrm{E}\left\{\varepsilon_{t}^{2} / F_{\mathrm{t}-1}\right\}$ is a nontrivial positive-value parametric function of $F_{\mathrm{t}-1}$. The sequence $\left\{\varepsilon_{t}\right\}$ may be observed directly or it may be an error or innovation sequence of an econometric model. In the latter case,

$$
\varepsilon_{t}=y_{t}-\mu_{t}\left(y_{t}\right)
$$


(1982) application was of this type. Engle assumed that $\varepsilon_{t}$ can be decomposed as:

$$
\varepsilon_{t}=z_{t} \sigma_{t}^{1 / 2}
$$

where $\left\{\mathrm{z}_{\mathrm{t}}\right\}$ is a sequence of independent, identically distributed (iid) random variables with zero mean and unit variance. It implies $\mathrm{E}\left\{\varepsilon_{t} / F_{\mathrm{t}-1}\right\} \sim \mathrm{D}\left(0, \sigma_{\mathrm{t}}\right)$ where $\mathrm{D}$ stands for the distribution (typically assumed to be a normal or a leptokurtic one). The following conditional variance defines an $\mathrm{ARCH}$ model of order q:

$$
\begin{gathered}
\sigma_{t}^{2}=\alpha_{0}+\sum_{j=1}^{q} \alpha_{j} \varepsilon_{t-j}^{2} \\
\text { For } \alpha_{0}>0, \alpha_{j} \geq 0, \quad j=1, \ldots, \mathrm{q}-1 \text {, and } \alpha_{\mathrm{q}}>0 .
\end{gathered}
$$

The parameter restrictions in (3) form a necessary and sufficient condition for strictly positive or non- negativity restriction of the conditional variance.

Formulating the variance equation, with the last period volatility, forms the ARCH term, and the last period variance, which forms the GARCH term, together with constant yield the following equation:

$$
\sigma_{t}^{2}=\alpha_{0}+\sum_{i=1}^{q} \alpha_{i} e_{t-1}^{2}+\sum_{j=1}^{p} \beta_{i} \sigma_{t-j}^{2}
$$

The autoregressive root, which governs persistence of volatility shocks, is the sum of $\alpha$ and $\beta$. If the sum of $\alpha$ and $\beta$ is greater or very close to unity then, the volatility persists overtime. According to equation (4), the error variance at time " $\mathrm{t}$ " is assumed to depend on previous squared error terms. Also, the variance at a time, " $\mathrm{t}$ " is conditional on those in previous periods and hence, the term conditional heteroscedasticity (Engle, 2004). 
Whereas there are other ARCH/GARCH family models such as GARCH-M models, Threshold GARCH models, IGARCH models and so forth, which may also be used to measure volatility, the classic GARCH model is widely used because it provides an easy interpretation of its results. It is appropriate for comparison purposes with results from other studies. One of the advantages of the GARCH model is that when estimated, it gives both ARCH and GARCH coefficients from which conclusions can be made. That is, if the sum of their coefficients is close or more than one, the prediction is that volatility persists over time rather than dying out. However, when the estimated results seem to violate non-negativity restriction of the conditional variance, the Exponential Generalised Autoregressive Conditional Heteroscedasticity (EGARCH) is estimated to account for that.

\subsection{Modelling Impact of Exchange Rate Volatility on Other Macroeconomic Variables in the EAC Member States}

\subsubsection{Functional Form of Variables}

After modelling the extent of exchange rate volatility in EAC member states, in a dynamic heterogeneous panel environment, the next step was to model exchange rate volatility on trade flows, FDI, inflation and interest rates. The idea is to find out whether or not exchange rate volatility caused volatility in trade flows, FDI, inflation and interest rates. The exchange rate used in this study is the real effective exchange rates (REER), which takes into account any changes in relative prices and trades with trading partners; while the interest rate used refers to overall lending rate.

A general representation of the model is given by:

$$
\begin{gathered}
L V E X_{t}=\lambda_{10}+\lambda_{11} \sum_{i=1}^{k} V E X_{t-i}+\lambda_{12} \sum_{i=1}^{k} L E X P_{t-i}+\lambda_{13} \sum_{i=1}^{k} I N T_{t-i}+\lambda_{14} \sum_{i=1}^{k} L F D I_{t-i}+\lambda_{15} \sum_{i=1}^{k} I N F L_{t-i}+\varepsilon_{1 t} \\
L E X P_{t}=\lambda_{20}+\lambda_{21} \sum_{i=1}^{k} L V E X_{t-1}+\lambda_{22} \sum_{i=1}^{k} L E X P_{t-1}+\lambda_{23} \sum_{i=1}^{k} I N T_{t-1}+\lambda_{24} \sum_{i=1}^{k} L F D I_{t-1}+\lambda_{25} \sum_{i=1}^{k} I N F L_{t-1}+\varepsilon_{2 t} \\
I N T_{t}=\lambda_{30}+\lambda_{31} \sum_{i=1}^{k} L V E X_{t-i}+\lambda_{32} \sum_{i=1}^{k} L E X P_{t-i}+\lambda_{33} \sum_{i=1}^{k} I N T_{t-i}+\lambda_{34} \sum_{i=1}^{k} L F D I_{t-i}+\lambda_{35} \sum_{i=1}^{k} I N F L_{t-i}+\varepsilon_{3 t} \\
L F D I_{t}=\lambda_{40}+\lambda_{41} \sum_{i=1}^{k} L V E X_{t-i}+\lambda_{42} \sum_{i=1}^{k} L E X P_{t-i}+\lambda_{43} \sum_{i=1}^{k} I N T_{t-i}+\lambda_{44} \sum_{i=1}^{k} L F D I_{t-i}+\lambda_{45} \sum_{i=1}^{k} I N F L_{t-i}+\varepsilon_{3 t} \\
I N F L_{t}=\lambda_{50}+\lambda_{51} \sum_{i=1}^{k} L V E X_{t-i}+\lambda_{52} \sum_{i=1}^{k} L E X P_{t-i}+\lambda_{53} \sum_{i=1}^{k} I N T_{t-i}+\lambda_{54} \sum_{i=1}^{k} L F D I_{t-i}+\lambda_{55} \sum_{i=1}^{k} I N F L_{t-i}+\varepsilon_{3 t}
\end{gathered}
$$

Where VEX is volatility series of the real effective exchange rate, EXP is exports-proxy for trade flows, INT is interest rate--overall lending rate, FDI is foreign direct investment, INFL is inflation and $\mathcal{E}$ is error term.

\subsubsection{Estimation Technique}

The Panel Autoregressive Distributed Lag (ARDL) technique or pooled mean group (PMG) estimator was used to estimate the effects of exchange rate volatility on selected macroeconomic variables. The ARDL bound testing technique possesses several advantages when compared to other single equation estimation techniques like Engle-Granger and Fully Modified Ordinary Least Squares (FMOLS): foremost unlike ARDL, there are no formal tests for cointegration in Engle-Granger and FMOLS. Moreover, when compared to Engle-Granger, ARDL reduces the endogeneity issues and all the variables are implicitly assumed to be endogenous.

Also, the long run and short-run variables are estimated simultaneously, removing problems associated with omitted variables and autocorrelation. And lastly, the ARDL bound testing technique does not usually need information on the order of integration of variables, which is necessary for the Engle-Granger and Fully Modified OLS and also in the JML technique.

In the other techniques, it is necessary for the variables to have the same order of integration.3 Accordingly, a problem arises when the variables possess dissimilar orders of integration; to address this problem Pesaran et al. $(1996,2001)$ recommended the ARDL technique that does not involve the arrangement of variables into I (0) or I (1).

\footnotetext{
${ }^{3}$ Pesaran and Pesaran (1997, p. 291) points out that the residual-based cointegration are inefficient and can lead to misleading results, especially when there are more than two I(1) variables under consideration.
} 
Pesaran and Shin (1999) contended that the ARDL technique can be reliably employed in small samples to estimate and test hypotheses on the long-run coefficient in both cases where the underlying regressors are $\mathrm{I}(1)$ or $\mathrm{I}(0)$. Therefore, the current study employs the ARDL technique to examine the effects of exchange rate volatility on selected macroeconomic variables in East Africa.

The ARDL model (p, q, q, q) will take the following form:

$$
y_{i t}=\sum_{j=1}^{p} \lambda_{i j} y_{i, t-j}+\sum_{j=0}^{q} \delta_{i j}^{\prime} x_{i, t-j}+\mu_{i}+\varepsilon_{i t}
$$

where $y_{i t}$ denotes the dependent variables for group and $x_{i j}(\mathrm{k} \times 1)$ is the vector explanatory variables for group $i$, $\delta_{i j}^{\prime}$ are $(\mathrm{k} \times 1)$ coefficient vectors, groups are denoted by $i=1,2, \ldots, \mathrm{N}$, time periods by $\mathrm{t}=1,2, \ldots, \mathrm{T}$, whereas $\mu_{i}$ represents the fixed effects.

This model can be reparametrized as a VECM system:

$$
\Delta y_{i t}=\theta_{i}\left(y_{i, t-1}-\psi_{i} x_{i, t-1}\right)+\sum_{j=1}^{p-1} \lambda_{i j} \Delta y_{i, t-j}+\sum_{j=0}^{q-1} \delta_{i j} \Delta x_{i, t-j}+\mu_{i}+\varepsilon_{i t}
$$

In the above equation $\lambda_{i j}$ represents the long-run parameters and $\theta_{i}$ are error correction parameters. In the present analysis, $\mathrm{Y}$ represents exchange rate volatility, and $\mathrm{X}$ is a set of various explanatory variables including FDI, exports, inflation, and lending rate. The parameters on the left side in parenthesis are the long run and term on the right-hand side is short-run dynamics. The short-run parameter can be anticipated that has significant negative value under the pre-assumption that variables direct a convergence to long-term equilibrium.

The panel ARDL is consistent under the assumption of a long-run slope homogeneity (Ndambendia and Njoupouognigni, 2010). The key assumptions of the ARDL estimator are in this fashion: foremost, the error terms are assumed to be serially uncorrelated and are distributed independently of the regressors, explicitly, the explanatory variables can be treated as exogenous; moreover, there is a long-run relationship between the dependent and explanatory variables; and lastly, the long-run parameters are the same across countries.

\subsection{Data and Data Analysis}

The study utilized the monthly time series data covering the period 2002 - 2018. This period is selected to capture the period before and after the financial crisis of 2008, from which all EAC countries have been facing financial and economic challenges that emanated from the crisis. Also, in early 2015, all EAC currencies recorded a significant depreciation against other major currencies mainly on account of global appreciation of the US Dollar. Therefore, the exchange rates of these countries have been passing through some policy interventions. The major sources of data are EAC Central Banks and International Financial Statistics (IFS).

It has often been argued that macroeconomic data are characterized by a stochastic trend and, if unresolved, the statistical behaviour of the estimators will be influenced by such a trend such that results may be spurious. In this case, the unit root test was conducted to find out the stationarity of variables used in the estimation. The study applied the commonly used method to test for the presence of unit roots are the ADF tests (Dickey and Fuller, 1979 and 1981) as well as Phillip Perron (1988).

The following section applies the methodology to present findings on the extent of exchange rate volatility and its likely impact on macroeconomic variables. The data examination exercise is also presented in order to diagnose the behaviour of data used.

\section{Definition of variables}

The data set contains monthly measures on the following variables

1. The volatility of nominal exchange rate (LVEX): Estimated using EGARCH, ARCH and GARCH models introduced in section 5.2

2. Exports (LEXP): Total exports of goods and services (FOB), in millions of US Dollars, converted into logarithm

3. Interest Rate (INT): Overall lending rate, percent

4. Foreign direct investment (LFDI): Inward Foreign Direct Investment, in millions of US Dollars, converted into logarithm

5. Inflation (INFL): Year on year inflation rate expressed in percent 


\section{Discussion of Findings}

\subsection{Introduction}

This section presents empirical results from the estimated volatility model where the extent of exchange rate volatility is estimated and discussed. The estimation has been extended to assess the impact of exchange rate volatility on trade flows, FDI, inflation and interest rate from which the preliminary data diagnostics are first presented to describe the statistical behaviour of the variables used.

\subsection{Establishing the Presence or Absence of Volatility of Exchange Rate (VEX)}

All procedures for volatility estimation were conducted before and after estimation to ensure robustness. To ensure that appropriate mean equations were specified, both Q and Q-squared tests were employed. Also, the ARCH test was carried out before and after volatility estimation to ensure that ARCH effect exists and does not exists, respectively (not presented here).

Table 1 presents estimated results for the exchange rate volatility in Tanzania, Kenya and Uganda. Generally, results indicate the presence of exchange rate volatility in Tanzania, Kenya and Uganda as it has been described by either ARCH or/and GARCH coefficients. For the case of Tanzania and Uganda, the exchange rate volatilities were estimated using GARCH $(1,1)$ specification after minimization of both the Schwarz (SIC) and Akaike (AIC) criteria. More specifically, exchange rate volatility in Tanzania originated from the last variance (GARCH component) and it was statistically significant at 5 percent. Meanwhile, exchange rate volatility in Uganda was originated from both the way exchange rate deviates from its own mean (ARCH component) and last variance and was significant at 5 percent and 1 percent, respectively.

For the case of Kenya, the coefficient of the GARCH terms ( $\beta$ ) was negative (not presented here), which violated the non-negativity condition. To resolve the negativity problem, the exchange rate volatility was estimated using the EGARCH specification as proposed by Nelson (1991). The EGARCH model is specified as:

$$
\log \left(\delta_{t}^{2}\right)=\lambda+\alpha \log \left(\delta_{t-1}^{2}\right)+\beta\left|\frac{\varepsilon_{t-1}}{\delta_{t-1}}\right|+\gamma \frac{\varepsilon_{t-1}}{\delta_{t-1}}
$$

Where $\delta_{t}^{2}$ is the conditional variance of the exchange rate, $\varepsilon_{t-1}$ stands for the residuals and is the ARCH term, which measures information about volatility in the previous period, $\delta_{t-1}^{2}$ is the GARCH term representing the last period's forecast variance and $\lambda, \alpha, \beta$ and $\gamma$ are parameters to be estimated. Both AIC and SIC were minimized in the specification of the EGARCH $(1,1)$. Results indicate that the EGARCH coefficients of 0.9658 is positive and properly identified. This coefficient rectifies the aforementioned problem of negative coefficients. Results confirm that the volatility of the exchange rate was contributed by the last period's forecast variance in exchange rates.

Findings indicate that the sum of the ARCH and GARCH coefficients $(\alpha+\beta)$ for the case of Kenya and Uganda is very close to 1 , indicating that volatility shocks in exchange rates were quite persistent over time, while for Tanzania was not.

Table 1. Estimation Results of Exchange Rate Volatility

\begin{tabular}{|c|c|c|c|c|c|}
\hline & & Coefficient & Std. Error & z-Statistic & Prob. \\
\hline \multirow{3}{*}{ TANZANIA } & $\mathrm{C}$ & $1.40 \mathrm{E}-33$ & $1.09 \mathrm{E}-33$ & 1.2869 & 0.1981 \\
\hline & $\operatorname{RESID}(-1)^{\wedge} 2$ & 0.5903 & 0.4022 & 1.4675 & 0.1423 \\
\hline & GARCH $(-1)$ & 0.0104 & 0.0042 & $2.4792 * *$ & 0.0132 \\
\hline & & & & & \\
\hline \multirow{4}{*}{ KENYA } & $\mathrm{C}$ & -2.5239 & 0.9699 & -2.6022 & 0.0093 \\
\hline & $\mid \mathrm{RES} / \mathrm{SQR}[\mathrm{GARCH}](1)$ & 0.0789 & 0.0281 & $2.8152 *$ & 0.0049 \\
\hline & $\mathrm{RES} / \mathrm{SQR}[\mathrm{GARCH}](1)$ & 0.0603 & 0.6664 & 0.0905 & 0.9279 \\
\hline & EGARCH $(1)$ & 0.9658 & 0.2471 & $3.908^{*}$ & 0.0001 \\
\hline & & & & & \\
\hline \multirow{3}{*}{ UGANDA } & $\mathrm{C}$ & $2.50 \mathrm{E}-29$ & $1.52 \mathrm{E}-29$ & 1.6403 & 0.1009 \\
\hline & $\operatorname{RESID}(-1)^{\wedge} 2$ & 0.1501 & 0.0603 & $2.4892 * *$ & 0.0128 \\
\hline & $\operatorname{GARCH}(-1)$ & 0.8912 & 0.1797 & $4.9594 *$ & 0.0008 \\
\hline
\end{tabular}

Note: * and ** indicate significant at 1 and 5 percent level, respectively.

Source: Author's estimates. 
The comparison of the levels of exchange rate volatility in Tanzania, Kenya and Uganda is presented in the next sub-section using the means, variances and standard deviations. These indicate the country with a high or low level of exchange rate volatility in those countries.

\subsection{Descriptive Statistics}

\subsubsection{Summary}

Preliminary diagnostic tests were conducted to check the behaviour of the data used. The summary statistics of all variables used are presented in Annex 2. Results give important information about the macroeconomic variables in Tanzania, Kenya and Uganda.

Figure 16 illustrates that the coefficient of variation (defined as the ratio of the standard deviation to the mean) in the exchange volatility series was much higher in Uganda, followed by Tanzania during the study period. Therefore, the degree of exchange rate volatility was higher in Uganda and Tanzania and lower in Kenya.

Also, Uganda recorded the highest coefficient of variation in inflation and trade flows-proxied by exports compared to Kenya and Tanzania. Thus, the degree of deviation of the exchange rate volatility, inflation and exports from the mean value in Uganda is far more than in Kenya and Tanzania. On the other hand, Kenya recorded the highest coefficient of variation for FDI, and lending rates compared to Uganda and Tanzania.



Figure 13. Coefficient of variation

Source: Author's estimates

\subsection{Estimation of the Impact of Exchange Rate Volatility on Macroeconomic Variables}

\subsubsection{Panel Unit Root Test}

Several panel data unit root tests were conducted for all five variables and results from the Levin et al. (2002), Im et al. (2003) as well as Augmented Dickey-Fuller (1981) tests for variables at both levels as well after the first difference are summarized in Annex 3 and 4. Results suggest only exchange rate volatility series and inflation are stationary at level, all other variables are stationary after taking the first difference. Thus, we have equally observed that our data is suffering from either I (0) and I (1).

\subsubsection{Results of the ARDL Bound Estimations}

\section{Model 1: Determinants of Exchange Rate Volatility}

The long-run and short-run estimates of the drivers of volatility in the exchange rate are presented in Table 2. In the long-run volatility of exchange rate is impacted negatively by FDI flows and positively by exports at a 10 percent significance level. The coefficients of FDI and exports are statistically significant at the 10 percent level in Model 1 . The long-run result of the impact of FDI on the exchange rate is consistent with the proposition by Afridi (1995) and Edwards (1988) that the impact of FDI on exchange rate rests on whether proceeds from FDI are used for the purchase of tradable goods or non-tradable goods. For the case when the spending is made on the purchase of non-tradable goods will lead to an appreciation of the exchange rate and thus reduces the volatility which for the case of East African countries is mostly on the depreciating side. The same applies to the case of an increase in foreign exchanges.

In the short-run, however, the volatility of the exchange rate is predominantly impacted (negatively) by exports only. The error correction term (-0.12) in the short-run model is negative and significant implying that there is a long-run causality 
running from explanatory variables to the dependent variable. It also confirms that the speed of adjustment to long-run equilibrium is 12 percent monthly (since the dataset is monthly).

Table 2. ARDL Bound Results for Model 1

\begin{tabular}{|c|c|c|c|c|}
\hline \multicolumn{5}{|l|}{ Dependent Variable: D(LVEX) } \\
\hline \multicolumn{5}{|l|}{ Method: ARDL } \\
\hline \multicolumn{5}{|c|}{ Dynamic regressors (12 lags, automatic): INFL LFDI INT LEXPO } \\
\hline \multicolumn{5}{|c|}{ Fixed regressors: $\mathrm{C}$} \\
\hline \multicolumn{5}{|c|}{ Selected Model: ARDL $(2,1,1,1,1)$} \\
\hline Variable & Coefficient & Std. Error & t-Statistic & Prob.* \\
\hline \multicolumn{5}{|c|}{ Long Run Equation } \\
\hline INFL & -0.021513 & 0.034974 & -0.615127 & 0.5387 \\
\hline LFDI & -1.036256 & 0.535399 & -1.935483 & $0.0535 *$ \\
\hline INT & 0.148842 & 0.114235 & 1.302943 & 0.1932 \\
\hline LEXPO & 0.842311 & 0.470676 & 1.789576 & $0.0741 *$ \\
\hline \multicolumn{5}{|c|}{ Short Run Equation } \\
\hline COINTEQ01 & -0.120057 & 0.057307 & -2.094970 & $0.0367 * *$ \\
\hline D (LVEX (-1)) & 0.028769 & 0.158437 & 0.181581 & 0.8560 \\
\hline D(INFL) & 0.000730 & 0.004418 & 0.165291 & 0.8688 \\
\hline D(LFDI) & -0.070438 & 0.085961 & -0.819423 & 0.4129 \\
\hline D(INT) & -0.039282 & 0.033014 & -1.189882 & 0.2346 \\
\hline D(LEXPO) & -0.099073 & 0.033947 & -2.918469 & $0.0037 * * *$ \\
\hline $\mathbf{C}$ & -0.050162 & 0.034273 & -1.463601 & 0.1439 \\
\hline Mean dependent var & -0.013411 & \multicolumn{2}{|c|}{ S.D. dependent var } & 0.544169 \\
\hline S.E. of regression & 0.515956 & \multicolumn{2}{|c|}{ Akaike info criterion } & 1.547585 \\
\hline Sum squared resid & 137.0982 & \multicolumn{2}{|c|}{ Schwarz criterion } & 1.746269 \\
\hline Log likelihood & -392.8480 & \multicolumn{2}{|c|}{ Hannan-Quinn criter. } & 1.625290 \\
\hline
\end{tabular}

\section{Model 2: Impact of Exchange rate volatility on exports}

The exchange rate volatility is noticed to positively affect the exports in the long-run, at the 1 percent level of significance (Annex 5). The results indicate that for a 1 percent increase in exchange rate volatility raises exports by 0.13 percent. In the short-run model, though not statistically significant, the volatility of the exchange rate is noticed to negatively affect export consistent with prior expectation. A reasonable clarification may perhaps be that at the occurrence of increasing volatility, risk-averse traders would immediately hold back on their high-risk exporting commitments in efforts to reduce likely trade losses. The significance of the error correction term in the model suggests that both long-run and short-run models can be estimated.

The short-run findings of the study are consistent with the findings from the study by Choudhury (2005), Arize, Osang, and Slottje (2004) and Clark (1973) that exchange rate volatility has a negative impact on the export demand in the short-run. However, in the long-run, the findings of the current study are contrary to the findings of the aforementioned studies.

\section{Model 3: Impact of Exchange rate volatility on lending rates}

The exchange rate volatility is noticed to positively affect the lending rates in the long-run, at the 1 percent level of significance (Annex 6). The results indicate that for a 1 percent increase in exchange rate volatility raises exports by 0.97 percent. In the short-run model, lending rates are also positively and significantly affected by exports.

The long-run and the short-run findings of the study is consistent with the findings from the study by Karfakis and Kim (1995) which discovered that unanticipated nominal exchange rate volatility is linked with and an increase in interest rates through its impact on current account deficit.

\section{Model 4: Impact of Exchange rate volatility on FDI}

From Annex 7, the significance of the error correction term in the model suggests that both long-run and short-run models can be estimated. The exchange rate volatility is observed to negatively affect the FDI in the long-run, at the 1 percent level of significance. The results indicate that for a 1 percent increase in exchange rate volatility reduces FDI by 0.23 percent in the long run. In the short-run model, all explanatory variables are observed to be statistically insignificant.

These findings are in line with the findings of Accam (1997) and Alaba (2003) which examined the relationship between exchange rate volatility and FDI flows over time. The results of the two studies indicate that the official market exchange rate movement significantly reduces FDI inflows. However, findings of the current study are contrary to findings by 
Chaduhary et al. (2012) as well as Cushman (1988), Stokman and Vlar (1996), and Foad (2005) which indicate a positive impact of exchange rate volatility on FDI flow to the host countries.

\section{Model 5: Impact of Exchange rate volatility on inflation}

As reported in Annex 8, the exchange rate volatility exerts a positive insignificant effect on inflation in the long-run. This finding is consistent with findings of the study by Edwards (1993) who conducted the cross-country research in developing countries as well as that of Odedokun (1995), using data from 35 countries for the period 1971 to 1990 where the domestic currency volatility was found to exert positive effects on inflation. In the short-run model, the volatility of the exchange rate is noticed to negatively affect inflation contrary to prior expectation.

\subsubsection{Granger Causality Tests}

The pairwise Granger causality test, as well as pairwise Dumitrescu-Hurlin Panel causality test for all variables used, are presented in Annex 10 and Annex 11. For the case of pairwise Granger causality test that assumes common coefficients, there is unidirectional causality between volatility in lending rate and inflation; and lending rate and exports at 1 percent significant level.

For the case of Dumitrescu-Hurlin Panel causality test, four bi-directional causalities and one uni-direction causality have been detected. there is unidirectional causality between volatility in lending rate and inflation; and lending rate and exports. There was bi-directional causality between the lending rate and inflation, FDI and inflation, the volatility of exchange rate and inflation as well as the volatility of exchange rate and exports. The uni-direction causality runs from the volatility of the exchange rate to FDI and not otherwise.

\section{Conclusions and Policy Implications}

This study estimated the extent of exchange rate volatility and assessed its subsequent impact on macroeconomic variables, basically, trade flows, FDI, interest rate and inflation in Tanzania, Kenya and Uganda. The exchange rate used in this study is the real effective exchange rates (REER), which takes into account any changes in relative prices and trades with trading partners. Also, the interest rate which was used was the overall lending rate. To estimate exchange rate volatility, the study used the ARCH/GARCH family models, which assume that volatility changes over time. At the same time, the Panel Autoregressive Distributed Lag (ARDL) bound testing technique or pooled mean group (PMG) estimator was used to assess the impact of exchange rate volatility on macroeconomic variables.

The results confirm that volatility in the exchange rate is a practical issue in all the sampled countries and is fundamentally driven by exports dynamics for the period under consideration.

With respect to exports, the results indicate a positive impact of the exchange rate volatility to export performance in the long run. However, in the short run, exchange rate volatility seems to be detrimental to export performance.

For the case of lending rates, results suggest that volatility in the exchange rate raises lending rates in the long run but reduces lending rates in the short-run period. The long-run response, excess exchange rate volatility can lead to higher prices of tradable goods by causing traders to incorporate a risk premium to accommodate unanticipated exchange rate volatilities from which inflationary pressures cause banks to increase lending rates to hedge themselves.

The response of FDI seems to be different. While there was a negative response of FDI in the long run, the short responses from the volatility of the real exchange rate seem to be insignificant. For the case of long-run response, this is due to the fact that excessive volatility in exchange rate creates a high degree of currency risk, which alters the flow of FDI to countries with more unstable exchange rates.

With respect to inflation, though not significant, the volatility of the exchange rate appears to have a positive impact on inflation.

Two major policy implications can be drawn based on the findings of the relationship between exchange rate volatility and macroeconomic variables in EAC countries.

First, policymakers need institute mitigation measures, which could reduce exchange rate volatility to minimize its likely impact on the economy. The EAC central banks may think to keep enough reserves, which will be used as intervening tools in stabilizing exchange rate fluctuations. Also, most EAC countries are still depending on traditional exports as a means of foreign exchange earnings, which are subjected to low prices in the world market. There is a need to fast-track industrialization agenda, which will promote manufacturing sector in order to create value addition and not only be able to earn more foreign exchange but also solve problems emanated from the inflationary pressure induced by the exchange rate volatility.

Second, for the case of Tanzania and Kenya, where the Pairwise Dumitrescu-Hurlin Panel Causality Tests indicated the bi-directional causality between exchange rate volatility and inflation, there is a need to consider adopting inflation targeting monetary policy framework in order to contain inflation at the appropriate level. Further study is 
recommended to investigate the impact of exchange rate volatility in EAC economies using alternative methods such as panel vector error correction model.

This study contributes to closing the gap on theoretical and empirical literature by providing new evidence on the extent of exchange rate volatility and its impact on key macroeconomic variables such as flows, FDI, interest rate and inflation in the East African countries. The results of this study provide strong evidence that exchange rate volatility is a real issue in all the sampled countries and is fundamentally driven by exports and FDI dynamics for the period under consideration. Moreover, the results indicate a positive impact of the exchange rate volatility to export performance, inflation and lending rates in the long run. On the other hand, the response of FDI to exchange rate volatility seems to be negative in the long run. Another contribution of this study is that the findings of the research provide an important guide in designing appropriate macroeconomic policies such as fiscal, monetary, trade, industrial and investment policies to enhance sustainable development.

\section{References}

Accam, B. (1997). Survey of measurement of exchange rate instability (Staff Papers Vol. 31, No. 2). IMF.

Adler, M., \& Dumas, B. (1984). Exposure to currency risk: definition and measurement. Journal of Financial Management, 13, 41-50. https://doi.org/10.2307/3665446

Afridi, U. (1995). Determining real exchange rates. Pakistan Development Review, 34(3), 263-76. https://doi.org/10.30541/v34i3pp.263-276

Alaba, O. (2003, September). Exchange rate uncertainty and foreign direct investment in Nigeria. Paper presented at the WIDER conference on sharing global prosperity, Helsinki, Finland.

Arize, A., Osang T., \& Slottje D. (2000). Exchange rate volatility and foreign trade: evidence from thirteen LDC's. Journal of Business and Economics Statistics, 18(1), 10-17. https://doi.org/10.1080/07350015.2000.10524843

Bank of Tanzania. (2014). Monetary policy statement report. Dar es Salaam.

Bank of Uganda. (2016). Annual report for 2015/16. Kampala.

Bleaney, M., \& Francisco, M. (2008). What makes currencies volatile? An empirical investigation (Discussion Papers in economics No.8). University of Nottingham.

Brada, J. C., \& Mendez, J. A. (1988). Exchange rate risk, exchange rate regime and the volume of international trade. Kyklos, 41, 263-280. https://doi.org/10.1111/j.1467-6435.1988.tb02309.x

Broda, C. (2004). Term of trade and exchange rate regimes in developing countries. Journal of International Economics, 63(1), 31-58. https://doi.org/10.1016/S0022-1996(03)00043-6

Caballero, R. J., \& Corbo V. (1989). The effect of real exchange rate uncertainty on exports: empirical evidence. The World Bank Economic Review, 3, 263-278. https://doi.org/10.1093/wber/3.2.263

Campbell, J. Y., Lo A. W., \& MacKinlay, A. C. (1997). The econometrics of financial markets. New Jersey: Princeton University Press. https://doi.org/10.1515/9781400830213

Central Bank of Kenya. (2016). Quarterly economic review. Nairobi.

Chaudhary, G., Shah, S., \& Bagram, M. (2012). Do exchange rate volatility effects foreign direct investment? Evidence from selected Asian economies. Journal of Basic and Applied Scientific Research, 4, 3670-3681.

Choudhry, T. (2005). Exchange rate volatility and the United States exports: Evidence from Canada and Japan. Journal of the Japanese and International Economics, 19, 51-71. https://doi.org/10.1016/j.jjie.2003.11.002

Clark, P. B. (1973). Uncertainty, exchange risk, and the level of international trade. Western Economic Journal, 11, 302-13. https://doi.org/10.1111/j.1465-7295.1973.tb01063.x

Clark, P., Tamirisa N., Shang-Jin W., Sadikov A., \& Zeng L. (2004). Exchange rate volatility and trade flows: Some new evidence. IMF. https://doi.org/10.5089/9781589063587.084

Côté, A. (1994). Exchange rate volatility and trade - a survey (Working Paper 94-5). Bank of Canada.

Cushman, D. (1988). Real exchange rate risk, expectations and the level of direct investment. Review of Economics and Statistics, 67(2), 297-308. https://doi.org/10.2307/1924729

Danmola, R. A. (2013). The impact of exchange rate volatility on the macroeconomic variables in Nigeria. European Scientific Journal, 9(7).

Darby J., Hallet A. H., Ireland J., \& Piscitelli L. (1999). The impact of exchange rate uncertainty on the level of investment. The Economic Journal, 109, 55-67. https://doi.org/10.1111/1468-0297.00416 
De Grauwe, P. (1988). Exchange rate variability and the slowdown in growth of international trade (Staff Papers No. 35, pp 63-84). IMF. https://doi.org/10.2307/3867277

Dickey, D. A., \& Fuller, W. A. (1979). Distribution of the estimators for autoregressive time series with a unit root. Journal of the American Statistical Association, 74(366a), 427-431. https://doi.org/10.1080/01621459.1979.10482531

Dickey, D. A., \& Fuller, W. A. (1981). Likelihood ratio statistics for autoregressive time series with a unit root. Econometrica, 49, 1057-1072. https://doi.org/10.2307/1912517

Dixit, A., \& Pindyck, R. (1994). Investment under uncertainty. Princeton University Press. https://doi.org/10.1515/9781400830176

Edwards, S. (1988). The real and monetary determinants of real exchange rate behaviour: Theory and evidence from developing countries. Journal of Development Economics, 29(3), 11-41. https://doi.org/10.1016/0304-3878(88)90048-X

Edwards, S. (1993). The political economy of inflation and stabilization in developing countries (NBER Working Paper Series, No.4319). https://doi.org/10.3386/w4319

Engle, R. F. (1982). Autoregressive conditional heteroscedasticity with estimated of the variance of the United Kingdom inflation. Econometrica, 50(4). https://doi.org/10.2307/1912773

Engle, R. F. (2004). Risk and volatility: econometric models and financial practice. American Economic Review, 94, 405-420. https://doi.org/10.1257/0002828041464597

Ezirim, C. B., Edith A. A., \& Muoghalu, M. (2012). Autoregressive Distributed Lag Analysis of Interdependencies Between Inflation and Exchange Rates in Sub-Saharan Nigeria. Proceedings of the IABPAD Conference, 9(2), 1082-1093.

Farrell, V., DeRosa, D., \& McCown, T. (1983). Effects of exchange rate variability on international trade and other economic variables: A review of the literature (Staff Studies). Washington, DC: Federal Reserve System.

Foad, H. S. (2005). Exchange rate volatility and export oriented FDI (A Paper from Emory University). Atlanta. https://doi.org/10.2139/ssrn.706524

Franke, G. (1991). Exchange rate volatility and international trading strategy. Journal of International Money and Finance, 10, 292-307. https://doi.org/10.1016/0261-5606(91)90041-H

Gerardo, E., \& Felipe, L. (2002). The impact of G-3 exchange rate volatility on developing countries (Discussion Paper Series 16). Harvard University.

Goldberg, L. S., \& Kolstad, C. D. (1995). Foreign Direct Investment, Exchange Rate Variability and Demand Uncertainty. International Economic Review, 36, 855-873. https://doi.org/10.2307/2527262

Hagen, J., \& Zhou, J. (2005). The choice of exchange rate regimes: An empirical analysis for transition economies. Economics of Transition, 13(4), 679-703. https://doi.org/10.1111/j.0967-0750.2005.00237.x

Hooper, P., \& Kohlhagen, S. W. (1978). The effect of exchange rate uncertainty on the prices and volume of international trade. Journal of International Economics, 8, 483-511. https://doi.org/10.1016/0022-1996(87)90001-8

Horvath, R. (2005). Exchange rate variability, pressures and optimum currency area criteria: Lessons for the central and eastern European countries. Working Paper 05/08. Czech National Bank.

Im, K., Pesaran M., \& Shin Y. (2003). Testing for unit roots in heterogeneous panels. Journal of Econometrics, 115(1), 53-74. https://doi.org/10.1016/S0304-4076(03)00092-7

IMF. (1984). Exchange rate volatility and world trade. Occasional Paper 28. Washington, DC: International Monetary Fund.

Johansen, S. (1991). Estimation and hypothesis testing of cointegration vectors in gaussian vector autoregressive models. Econometrica, 59(6), 1551-1580. https://doi.org/10.2307/2938278

Karfakis, C., \& Kim, S. (1995). Exchange rates, interest rates and current account news: some evidence from Australia. Journal of International Money and Finance, 14(4), 575-595. https://doi.org/10.1016/0261-5606(95)00020-F

Levin, A., Lin, C., \& Chu, J. (2002). Unit root tests in panel data: asymptotic and definite-sample properties. Journal of Econometrics, 108(1), 1-24. https://doi.org/10.1016/S0304-4076(01)00098-7

Luehrman, T. A. (1991). Exchange rate changes and the distribution of industry value. Journal of International Business Studies, 22, 619-649. https://doi.org/10.1057/palgrave.jibs.8490317 
McKenzie, M. (1999). The impact of exchange rate volatility on international trade flows. Journal of Economic Surveys, 13(1), 71-106. https://doi.org/10.1111/1467-6419.00075

McKinnon, R., \& Ohno, K. (1997). Dollar and Yen, resolving economic conflict between the United States and Japan. Cambridge MA: USA MIT Press.

Ndambendia, H., \& Njoupouognigni, M. (2010). Foreign aid, foreign direct investment and economic growth in sub-Saharan Africa: Evidence from pooled mean group estimator. International Journal of Economics and Finance, 2(3). https://doi.org/10.5539/ijef.v2n3p39

Odedokun, M. O. (1995). Analysis of probability of external debt rescheduling in sub-Saharan Africa. Scottish Journal of Political Economy, 42(1), 82-98. https://doi.org/10.1111/j.1467-9485.1995.tb01147.x

Ozturk, I. (2006). Exchange rate volatility and trade: A literature survey. International Journal of Applied Econometrics and Quantitative Studies, 3(1), 85-102.

Pesaran, M. H., \& Shin, Y. (1999). An autoregressive distributed lag modelling approach to cointegration analysis. Cambridge University Press.

Pesaran, M. H., \& Shin, Y. (2001). Bounds testing approaches to the analysis of long-run relationship. Journal of Applied Econometrics, 16, 289-326. https://doi.org/10.1002/jae.616

Pesaran, M. H., Shin, Y., \& Smith, R. J. (1996). Testing for the existence of a long-run relationship (DAE Working Papers Amalgamated Series, No.9622). University of Cambridge.

Phillips, C. B., \& Perron, P. (1988). Testing for a unit root in time series regression. Biometrika, 75, 335-346. https://doi.org/10.1093/biomet/75.2.335

Republic of Kenya. (2012). Economic Survey. Government Printer.

Schnabl, G. (2009). Exchange rate volatility and growth in emerging Europe and East Asia. Open Economies Review, 20, 565-587. https://doi.org/10.1007/s11079-008-9084-6

Sercu, P., \& Vanhulle, C. (1992). Exchange rate volatility, international trade, and the value of exporting firm. Journal of Banking and Finance, 16, 152-182. https://doi.org/10.1016/0378-4266(92)90083-C

Stokman, A. C., \& Vlar, P. J. (1996). Volatility, International Trade and Capital Flows. Amsterdam. https://doi.org/10.1007/978-1-4613-1271-0_7

UK Treasury. (2003). EMU and trade. Retrieved from http://www.hm-treasury.gov.uk/documents/the-euro/assessment/studies/euro.

Were, M., Alemayehu G., Ndung'u, N., \& Karingi S. (2002). Analysis of Kenya's export performance: An empirical evaluation (KIPPRA Discussion Paper Series 22). Nairobi: The Kenya Institute for Public Policy Research and Analysis.

World Bank. (2013). The Kenya Economic Update: Time to Shift Gears; Accelerating Growth and Poverty Reduction in the New Kenya (Edition No.8). Washington, DC. 


\section{ANNEX}

Annex 1. Graphical Presentation of Variables



Annex 2. Descriptive Statistics

\begin{tabular}{|l|c|c|c|c|c|c|c|}
\hline & Observations & Mean & Median & Std. Dev. & Coefficient of Variation & Maximum & Minimum \\
\hline INFL & 540 & 8.33 & 6.80 & 4.97 & 0.60 & 31.54 & -3.50 \\
\hline INT & 540 & 17.34 & 16.29 & 3.32 & 0.19 & 27.58 & 11.97 \\
\hline VEX & 540 & 17.17 & 8.53 & 22.38 & 1.30 & 135.55 & 0.00 \\
\hline EXPO & 540 & 257.91 & 210.96 & 166.61 & 0.65 & 603.75 & 14.40 \\
\hline FDI & 540 & 61.15 & 53.69 & 47.17 & 0.77 & 173.94 & 1.77 \\
\hline
\end{tabular}

Source: Author's estimates 
Annex 3. Unit Root Tests (t-statistic) in levels

\begin{tabular}{|c|c|c|c|c|c|c|}
\hline \multirow[t]{2}{*}{ Variable } & \multicolumn{2}{|c|}{$\begin{array}{c}\text { Levin, Lin \& Chu } \\
\text { H0: Common unit roots } \\
\text { Ha: Stationarity }\end{array}$} & \multicolumn{2}{|c|}{$\begin{array}{l}\text { Im, Pesaran and Shin } \\
\text { H0: Individual unit roots } \\
\text { Ha: Stationarity }\end{array}$} & \multicolumn{2}{|c|}{$\begin{array}{l}\text { PP - Fisher Chi-square } \\
\text { H0: Individual unit roots } \\
\text { Ha: Stationarity }\end{array}$} \\
\hline & Level & First Difference & Level & First Difference & Level & First Difference \\
\hline VEX & $-1.75045^{* * *}$ & $-59.7121 * * *$ & $-3.20193 * * *$ & $-49.4310 * * *$ & $26.5747 * * *$ & $166.602 * * *$ \\
\hline INT & -0.87112 & $-25.3519 * * *$ & $-2.53953 * * *$ & $-23.9564 * * *$ & $17.2461 * * *$ & $278.636^{* * *}$ \\
\hline INFL & $0.0494 * * *$ & $0.0479 * * *$ & $0.0129 * * *$ & $0.0007 * * *$ & 0.3987 & $0.0000 * * *$ \\
\hline EXPO & 0.10996 & $-15.3499 * * *$ & 0.47455 & $-19.2099 * * *$ & 2.72666 & $224.281 * * *$ \\
\hline FDI & 0.52743 & $-28.9322 * * *$ & 0.62006 & $-23.8096 * * *$ & 4.00117 & $289.741 * * *$ \\
\hline
\end{tabular}

$* * *$ denotes significance at $1 \%, * *$ denotes significance at $5 \%$

Annex 4. Unit Root Tests (t-statistic) in logs

\begin{tabular}{|c|c|c|c|c|c|c|}
\hline \multirow[t]{2}{*}{ Variable } & \multicolumn{2}{|c|}{$\begin{array}{c}\text { Levin, Lin \& Chu } \\
\text { H0: Common unit roots } \\
\text { Ha: Stationarity }\end{array}$} & \multicolumn{2}{|c|}{$\begin{array}{c}\text { Im, Pesaran and Shin } \\
\text { H0: Individual unit roots } \\
\text { Ha: Stationarity }\end{array}$} & \multicolumn{2}{|c|}{$\begin{array}{c}\text { PP - Fisher Chi-square } \\
\text { H0: Individual unit roots } \\
\text { Ha: Stationarity }\end{array}$} \\
\hline & Level & First Difference & Level & First Difference & Level & First Difference \\
\hline $\log (\mathbf{V E X})$ & -0.64671 & $-27.9218 * * *$ & $-1.89651 * *$ & $-25.7812 * * *$ & $13.9610 * *$ & $268.238 * * *$ \\
\hline INT & -0.87112 & $-25.3519 * * *$ & $-2.53953 * * *$ & $-23.9564 * * *$ & $17.2461 * * *$ & $278.636 * * *$ \\
\hline INFL & $0.0494 * * *$ & $0.0479 * * *$ & $0.0129 * * *$ & $0.0007 * * *$ & 0.3987 & $0.0000 * * *$ \\
\hline $\log ($ EXPO) & $-2.81141 * * *$ & $-20.3712 * * *$ & -0.89569 & $-21.6380 * * *$ & 7.17129 & $258.511 * * *$ \\
\hline $\log ($ FDI $)$ & -0.86845 & $-23.6302 * * *$ & -0.32887 & $-19.4491 * * *$ & 5.30790 & $193.228 * * *$ \\
\hline
\end{tabular}

$* * *$ denotes significance at $1 \%, * *$ denotes significance at $5 \%$

Annex 5. ARDL Results for Model 2

\begin{tabular}{|c|c|c|c|c|}
\hline \multicolumn{5}{|c|}{ Dependent Variable: D(LEXPO) } \\
\hline \multicolumn{5}{|l|}{ Method: ARDL } \\
\hline \multicolumn{5}{|l|}{ Included observations: 504} \\
\hline \multicolumn{5}{|c|}{ Maximum dependent lags: 12 (Automatic selection) } \\
\hline \multicolumn{5}{|c|}{ Model selection method: Akaike info criterion (AIC) } \\
\hline \multicolumn{5}{|c|}{ Dynamic regressors (12 lags, automatic): LVEX INFL LFDI INT } \\
\hline \multicolumn{5}{|l|}{ Fixed regressors: $\mathrm{C}$} \\
\hline \multicolumn{5}{|c|}{ Number of models evaluated: 144} \\
\hline \multicolumn{5}{|c|}{ Selected Model: ARDL $(12,1,1,1,1)$} \\
\hline \multicolumn{5}{|c|}{ Note: final equation sample is larger than selection sample } \\
\hline Variable & Coefficient & Std. Error & t-Statistic & Prob.* \\
\hline \multicolumn{5}{|c|}{ Long Run Equation } \\
\hline LVEX & 0.129238 & 0.045712 & 2.827228 & $0.0049 * * *$ \\
\hline INFL & 0.027111 & 0.012670 & 2.139782 & $0.0329 * *$ \\
\hline LFDI & 0.789199 & 0.087089 & 9.061997 & $0.0000 * * * *$ \\
\hline INT & -0.032411 & 0.057107 & -0.567555 & 0.5706 \\
\hline \multicolumn{5}{|c|}{ Short Run Equation } \\
\hline COINTEQ01 & -0.098296 & 0.060415 & -1.627021 & 0.1044 \\
\hline D(LEXPO(-1)) & -0.457536 & 0.069664 & -6.567792 & $0.0000 * * *$ \\
\hline D(LEXPO(-2)) & -0.342208 & 0.034881 & -9.810703 & $0.0000 * * *$ \\
\hline D(LEXPO(-3)) & -0.213579 & 0.033186 & -6.435844 & $0.0000 * * *$ \\
\hline
\end{tabular}




\begin{tabular}{|c|c|c|c|c|}
\hline D(LEXPO(-4)) & -0.237023 & 0.059979 & -3.951778 & $0.0001 * * *$ \\
\hline D(LEXPO(-5)) & -0.276905 & 0.075222 & -3.681159 & $0.0003 * * *$ \\
\hline D(LEXPO(-6)) & -0.234439 & 0.053095 & -4.415474 & $0.0000 * * *$ \\
\hline D(LEXPO(-7)) & -0.343691 & 0.047275 & -7.270022 & $0.0000 * * *$ \\
\hline D(LEXPO(-8)) & -0.237094 & 0.139332 & -1.701652 & $0.0895^{*}$ \\
\hline D(LEXPO(-9)) & -0.231665 & 0.105308 & -2.199894 & $0.0283 * *$ \\
\hline D(LEXPO $(-10))$ & -0.240762 & 0.044014 & -5.470184 & $0.0000 * * *$ \\
\hline D(LEXPO(-11)) & -0.155698 & 0.015683 & -9.927997 & $0.0000 * * *$ \\
\hline D(LVEX) & -0.020347 & 0.012634 & -1.610512 & 0.1079 \\
\hline D(INFL) & 0.016538 & 0.009759 & 1.694642 & $0.0908 *$ \\
\hline D(LFDI) & -0.037184 & 0.037572 & -0.989676 & 0.3228 \\
\hline D(INT) & 0.013440 & 0.006182 & 2.174125 & $0.0302 * *$ \\
\hline $\mathbf{C}$ & 0.226130 & 0.144372 & 1.566305 & 0.1179 \\
\hline Mean dependent var & 0.008978 & \multicolumn{2}{|c|}{ S.D. dependent var } & 0.155579 \\
\hline S.E. of regression & 0.125549 & \multicolumn{2}{|c|}{ Akaike info criterion } & -1.195389 \\
\hline Sum squared resid & 7.644877 & \multicolumn{2}{|c|}{ Schwarz criterion } & -0.758285 \\
\hline Log likelihood & 377.7550 & \multicolumn{2}{|c|}{ Hannan-Quinn criter. } & -1.024439 \\
\hline
\end{tabular}

Annex 6. ARDL Results for Model 3

\begin{tabular}{|c|c|c|c|c|}
\hline \multicolumn{5}{|l|}{ Dependent Variable: D(INT) } \\
\hline \multicolumn{5}{|l|}{ Method: ARDL } \\
\hline \multicolumn{5}{|c|}{ Dynamic regressors (12 lags, automatic): LEXPO LVEX INFL LFDI } \\
\hline \multicolumn{5}{|l|}{ Fixed regressors: $\mathrm{C}$} \\
\hline \multicolumn{5}{|c|}{ Selected Model: ARDL $(3,1,1,1,1)$} \\
\hline Variable & Coefficient & Std. Error & t-Statistic & Prob.* \\
\hline \multicolumn{5}{|c|}{ Long Run Equation } \\
\hline LEXPO & 1.823200 & 0.748302 & 2.436448 & $0.0152 * *$ \\
\hline LVEX & 0.979007 & 0.301186 & 3.250506 & $0.0012 * * *$ \\
\hline INFL & 0.207854 & 0.060612 & 3.429225 & $0.0007 * * *$ \\
\hline LFDI & -0.472167 & 0.983174 & -0.480248 & 0.6313 \\
\hline \multicolumn{5}{|c|}{ Short Run Equation } \\
\hline COINTEQ01 & -0.107388 & 0.082300 & -1.304848 & 0.1925 \\
\hline D(INT(-1)) & -0.093303 & 0.121454 & -0.768213 & 0.4427 \\
\hline D (INT(-2)) & -0.068247 & 0.063523 & -1.074365 & 0.2832 \\
\hline D(LEXPO) & 0.231170 & 0.052317 & 4.418619 & $0.0000 * * *$ \\
\hline D(LVEX) & -0.091135 & 0.040783 & -2.234602 & $0.0259 * *$ \\
\hline D(INFL) & -0.032395 & 0.036303 & -0.892353 & 0.3726 \\
\hline D(LFDI) & 0.539246 & 0.326419 & 1.652003 & $0.0991 *$ \\
\hline C & 1.034951 & 0.953743 & 1.085147 & 0.2784 \\
\hline Mean dependent var & -0.006977 & \multicolumn{2}{|c|}{ S.D. dependent var } & 0.734460 \\
\hline S.E. of regression & 0.660211 & \multicolumn{2}{|c|}{ Akaike info criterion } & 1.766178 \\
\hline Sum squared resid & 223.1700 & \multicolumn{2}{|c|}{ Schwarz criterion } & 1.988704 \\
\hline Log likelihood & -448.8681 & \multicolumn{2}{|c|}{ Hannan-Quinn criter. } & 1.853207 \\
\hline
\end{tabular}


Annex 7. ARDL Results for Model 4

\begin{tabular}{|c|c|c|c|c|}
\hline \multicolumn{5}{|l|}{ Dependent Variable: D(LFDI) } \\
\hline \multicolumn{5}{|l|}{ Method: ARDL } \\
\hline \multicolumn{5}{|c|}{ Dynamic regressors (12 lags, automatic): INT LEXPO LVEX INFL } \\
\hline \multicolumn{5}{|l|}{ Fixed regressors: $\mathrm{C}$} \\
\hline \multicolumn{5}{|c|}{ Selected Model: ARDL $(1,1,1,1,1)$} \\
\hline Variable & Coefficient & Std. Error & t-Statistic & Prob.* \\
\hline \multicolumn{5}{|c|}{ Long Run Equation } \\
\hline INT & 0.066278 & 0.043829 & 1.512201 & 0.1311 \\
\hline LEXPO & 0.506001 & 0.102604 & 4.931577 & $0.0000 * * *$ \\
\hline LVEX & -0.237579 & 0.064342 & -3.692439 & $0.0002 * * *$ \\
\hline INFL & 0.017663 & 0.011874 & 1.487570 & 0.1375 \\
\hline \multicolumn{5}{|c|}{ Short Run Equation } \\
\hline COINTEQ01 & -0.070638 & 0.029011 & -2.434892 & $0.0152 * *$ \\
\hline D(INT) & 0.024840 & 0.016062 & 1.546539 & 0.1226 \\
\hline D(LEXPO) & 0.039580 & 0.052741 & 0.750469 & 0.4533 \\
\hline D(LVEX) & 0.007843 & 0.005271 & 1.487940 & 0.1374 \\
\hline D(INFL) & -0.017530 & 0.018693 & -0.937780 & 0.3488 \\
\hline $\mathbf{C}$ & 0.059865 & 0.027141 & 2.205715 & $0.0278 * *$ \\
\hline Mean dependent var & 0.012347 & \multicolumn{2}{|c|}{ S.D. dependent var } & 0.197572 \\
\hline S.E. of regression & 0.190287 & \multicolumn{2}{|c|}{ Akaike info criterion } & -0.888698 \\
\hline Sum squared resid & 18.75626 & \multicolumn{2}{|c|}{ Schwarz criterion } & -0.713856 \\
\hline Log likelihood & 261.9484 & \multicolumn{2}{|c|}{ Hannan-Quinn criter. } & -0.820318 \\
\hline
\end{tabular}

Annex 8. ARDL Results for Model 5

\begin{tabular}{|c|c|c|c|c|}
\hline \multicolumn{5}{|l|}{ Dependent Variable: D(INFL) } \\
\hline \multicolumn{5}{|l|}{ Method: ARDL } \\
\hline \multicolumn{5}{|c|}{ Dynamic regressors (12 lags, automatic): LFDI INT LEXPO LVEX } \\
\hline \multicolumn{5}{|l|}{ Fixed regressors: $\mathrm{C}$} \\
\hline \multicolumn{5}{|c|}{ Selected Model: ARDL $(6,1,1,1,1)$} \\
\hline Variable & Coefficient & Std. Error & t-Statistic & Prob.* \\
\hline \multicolumn{5}{|c|}{ Long Run Equation } \\
\hline LFDI & -0.566533 & 1.180872 & -0.479758 & 0.6316 \\
\hline INT & -0.584238 & 0.476580 & -1.225895 & 0.2208 \\
\hline LEXPO & 2.223681 & 1.655555 & 1.343163 & 0.1798 \\
\hline LVEX & 0.548965 & 0.499401 & 1.099248 & 0.2722 \\
\hline \multicolumn{5}{|c|}{ Short Run Equation } \\
\hline COINTEQ01 & -0.071335 & 0.013581 & -5.252639 & $0.0000 * * *$ \\
\hline D(INFL(-1)) & 0.209546 & 0.020746 & 10.10064 & $0.0000 * * *$ \\
\hline D(INFL(-2)) & 0.168784 & 0.006419 & 26.29505 & $0.0000 * * *$ \\
\hline D(INFL(-3)) & 0.126195 & 0.021008 & 6.007111 & $0.0000 * * *$ \\
\hline D(INFL(-4)) & -0.036288 & 0.066940 & -0.542097 & 0.5880 \\
\hline D(INFL(-5)) & -0.001996 & 0.088003 & -0.022680 & 0.9819 \\
\hline D(LFDI) & -0.061789 & 0.818413 & -0.075498 & 0.9398 \\
\hline $\mathrm{D}(\mathrm{INT})$ & 0.191902 & 0.219927 & 0.872570 & 0.3833 \\
\hline D(LEXPO) & 0.690801 & 0.213637 & 3.233536 & $0.0013 * * *$ \\
\hline D(LVEX) & -0.143573 & 0.080037 & -1.793839 & $0.0734 *$ \\
\hline $\mathrm{C}$ & 0.627710 & 0.218044 & 2.878828 & $0.0042 * * *$ \\
\hline Mean dependent var & 0.023373 & \multicolumn{2}{|c|}{ S.D. dependent var } & 1.381138 \\
\hline S.E. of regression & 1.185584 & \multicolumn{2}{|c|}{ Akaike info criterion } & 3.052135 \\
\hline Sum squared resid & 707.0215 & \multicolumn{2}{|c|}{ Schwarz criterion } & 3.346187 \\
\hline Log likelihood & -787.0764 & \multicolumn{2}{|c|}{ Hannan-Quinn criter. } & 3.167138 \\
\hline
\end{tabular}


Annex 9. Lag length selection

VAR Lag Order Selection Criteria

Endogenous variables: INFL INT LEXPO LFDI LVEX

Exogenous variables: $\mathrm{C}$

Date: 04/07/19 Time: 09:23

Sample: 2002M01 2016M12

Included observations: 516

\begin{tabular}{|c|c|c|c|c|c|c|}
\hline Lag & $\log L$ & LR & FPE & AIC & $\mathrm{SC}$ & HQ \\
\hline 0 & -5317.914 & NA & 627.7005 & 20.63145 & 20.67259 & 20.64757 \\
\hline 1 & -1508.396 & 7530.443 & 0.000267 & 5.962773 & $6.209640 *$ & 6.059513 \\
\hline 2 & -1445.780 & 122.5622 & 0.000231 & 5.816975 & 6.269564 & $5.994331 *$ \\
\hline 3 & -1408.938 & 71.39762 & $0.000221^{*}$ & $5.771079 *$ & 6.429390 & 6.029051 \\
\hline 4 & -1388.312 & 39.57356 & 0.000225 & 5.788032 & 6.652065 & 6.126619 \\
\hline 5 & -1376.977 & 21.52862 & 0.000237 & 5.840995 & 6.910751 & 6.260199 \\
\hline 6 & -1357.998 & 35.67705 & 0.000243 & 5.864333 & 7.139811 & 6.364153 \\
\hline 7 & -1339.286 & 34.81384 & 0.000249 & 5.888704 & 7.369904 & 6.469140 \\
\hline 8 & -1314.664 & $45.32973^{*}$ & 0.000249 & 5.890172 & 7.577094 & 6.551224 \\
\hline \multicolumn{7}{|c|}{$\begin{array}{l}\text { dicates lag order selected by the } \\
\text { sequential modified LR test stat } \\
\text { Final prediction error } \\
\text { Schaike information criterion } \\
\text { Hannan-Quinn information crite }\end{array}$} \\
\hline
\end{tabular}

Annex 10. Panel Causality Test-Stacked Test/Common coefficients

\begin{tabular}{|c|c|c|c|}
\hline Null Hypothesis: & Obs & F-Statistic & Prob. \\
\hline INT does not Granger Cause INFL & 252 & 1.03524 & 0.3567 \\
\hline INFL does not Granger Cause INT & & 7.37499 & $0.0008 * * *$ \\
\hline LEXPO does not Granger Cause INFL & 252 & 1.00902 & 0.3661 \\
\hline INFL does not Granger Cause LEXPO & & 0.00888 & 0.9912 \\
\hline LFDI does not Granger Cause INFL & 252 & 0.28763 & 0.7503 \\
\hline INFL does not Granger Cause LFDI & & 1.46868 & 0.2322 \\
\hline LVEX does not Granger Cause INFL & 252 & 0.47962 & 0.6196 \\
\hline INFL does not Granger Cause LVEX & & 1.81184 & 0.1655 \\
\hline LEXPO does not Granger Cause INT & 252 & 2.19008 & 0.1141 \\
\hline INT does not Granger Cause LEXPO & & 5.67927 & $0.0039 * * *$ \\
\hline LFDI does not Granger Cause INT & 252 & 0.62553 & 0.5358 \\
\hline INT does not Granger Cause LFDI & & 1.05817 & 0.3487 \\
\hline LVEX does not Granger Cause INT & 252 & 0.70908 & 0.4931 \\
\hline INT does not Granger Cause LVEX & & 0.92854 & 0.3965 \\
\hline LFDI does not Granger Cause LEXPO & 252 & 0.08193 & 0.9214 \\
\hline LEXPO does not Granger Cause LFDI & & 0.91263 & 0.4028 \\
\hline LVEX does not Granger Cause LEXPO & 252 & 2.21957 & 0.1108 \\
\hline LEXPO does not Granger Cause LVEX & & 0.52291 & 0.5934 \\
\hline LVEX does not Granger Cause LFDI & 252 & 0.08281 & 0.9206 \\
\hline LFDI does not Granger Cause LVEX & & 0.46545 & 0.6284 \\
\hline
\end{tabular}


Annex 11. Pairwise Dumitrescu-Hurlin Panel Causality Tests

\begin{tabular}{|c|c|c|c|}
\hline Null Hypothesis: & W-Stat. & Zbar-Stat. & Prob. \\
\hline INT does not homogeneously cause INFL & 8.95333 & 9.28517 & $0.0000 * * *$ \\
\hline INFL does not homogeneously cause INT & 7.26400 & 7.30657 & $3 . \mathrm{E}-13 * * *$ \\
\hline LEXPO does not homogeneously cause INFL & 0.16144 & -1.01218 & 0.3114 \\
\hline INFL does not homogeneously cause LEXPO & 0.85226 & -0.20307 & 0.8391 \\
\hline LFDI does not homogeneously cause INFL & 13.1254 & 14.1717 & $0.0000 * * *$ \\
\hline INFL does not homogeneously cause LFDI & 3.16666 & 2.50764 & $0.0122 * * *$ \\
\hline LVEX does not homogeneously cause INFL & 11.2797 & 12.0098 & $0.0000 * * *$ \\
\hline INFL does not homogeneously cause LVEX & 2.79468 & 2.07196 & $0.0383 * * *$ \\
\hline LEXPO does not homogeneously cause INT & 0.16084 & -1.01288 & 0.3111 \\
\hline INT does not homogeneously cause LEXPO & 2.43931 & 1.65573 & 0.0978 \\
\hline LFDI does not homogeneously cause INT & 0.85090 & -0.20466 & 0.8378 \\
\hline INT does not homogeneously cause LFDI & 1.52951 & 0.59015 & 0.5551 \\
\hline LVEX does not homogeneously cause INT & 1.03737 & 0.01373 & 0.9890 \\
\hline INT does not homogeneously cause LVEX & 0.07857 & -1.10925 & 0.2673 \\
\hline LFDI does not homogeneously cause LEXPO & 1.18865 & 0.19093 & 0.8486 \\
\hline LEXPO does not homogeneously cause LFDI & 0.53052 & -0.57991 & 0.5620 \\
\hline LVEX does not homogeneously cause LEXPO & 4.18785 & 3.70368 & $0.0002 * * *$ \\
\hline LEXPO does not homogeneously cause LVEX & 3.34156 & 2.71248 & $0.0067 * * *$ \\
\hline LVEX does not homogeneously cause LFDI & 3.15052 & 2.48873 & $0.0128 * * *$ \\
\hline LFDI does not homogeneously cause LVEX & 0.66095 & -0.42714 & 0.6693 \\
\hline
\end{tabular}

Annex 12. Normality Test of Residuals

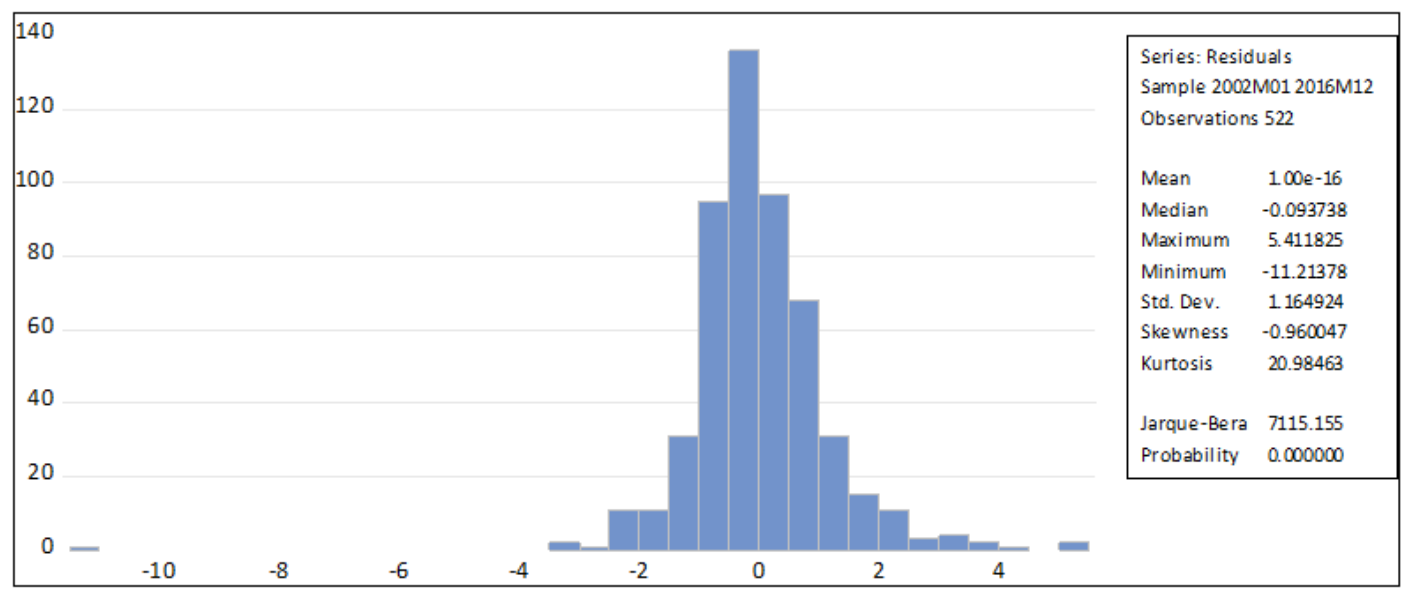

\section{Copyrights}

Copyright for this article is retained by the author(s), with first publication rights granted to the journal.

This is an open-access article distributed under the terms and conditions of the Creative Commons Attribution license which permits unrestricted use, distribution, and reproduction in any medium, provided the original work is properly cited. 